NBER WORKING PAPER SERIES

\title{
ADAPTING TO CIRCUMSTANCES: THE EVOLUTION OF WORK, SCHOOL, AND LIVING ARRANGEMENTS AMONG NORTH AMERICAN YOUTH
}

\author{
David Card \\ Thomas Lemieux
}

Working Paper 6142

\section{NATIONAL BUREAU OF ECONOMIC RESEARCH 1050 Massachusetts Avenue \\ Cambridge, MA 02138 \\ August 1997}

Prepared for the NBER Youth Unemployment and Employment in Advanced Countries Research Project. We are grateful to Francine Blau, David Blanchflower, Richard Freeman, and François Vaillancourt for comments and suggestions. Card's research was funded in part by a grant from the NICHD to the National Bureau of Economic Research, and by an NSF grant to the Center for Advanced Study in the Behavioral Sciences. Lemieux's research was funded in part by SSHRC, FCAR, and the Hoover Institution. This paper is part of NBER's research program in Labor Studies. Any opinions expressed are those of the authors and not those of the National Bureau of Economic Research.

1997 by David Card and Thomas Lemieux. All rights reserved. Short sections of text, not to exceed two paragraphs, may be quoted without explicit permission provided that full credit, including $O$ notice, is given to the source. 
Adapting to Circumstances: The Evolution

of Work, School, and Living Arrangements

Among North American Youth

David Card and Thomas Lemieux

NBER Working Paper No. 6142

August 1997

Labor Studies

\begin{abstract}
We use comparable micro data sets for the U.S. and Canada to study the responses of young workers to the external labor market forces that have affected the two countries over the past 25 years. We find that young workers adjust to changes in labor market opportunities through a variety of mechanisms, including changes in living arrangements, changes in school enrollment, and changes in work effort. In particular, we find that poor labor market conditions in Canada explain why the fraction of youth living with their parents has increased in Canada relative to the U.S. recently. Paradoxically, this move back home also explains why the relative position of Canadian youth in the distribution of family income did not deteriorate as fast as in the U.S.
\end{abstract}

David Card

Department of Economics University of California

Berkeley, CA 94720

and NBER

card@casbs.stanford.edu
Thomas Lemieux Department of Economics Université de Montréal C.P. 6128, succursale Centre-Ville Montréal, Québec H3C 3J7 CANADA and NBER

lemieuxt@plgcn.umontreal.ca 
The past three decades have witnessed a series of challenges to the economic well-being of youth in Canada and the United States. During the 1960s and early 1970s the "baby boom" led to a substantial increase in the relative fraction of young people in the population. This massive supply shock is generally thought to have exerted downward pressure on the relative earnings of younger workers. In the late 1970 s, just as the demographic bulge began to subside, the demand side turned against Icss-skilled workcrs, rcsulting in falling real wages for youth and other groups at the bottom of the labor market (see Levy and Murnane, 1992). Meanwhile, secular trends in family structure, including the rise in the fraction of children born out of wedlock and increasing divorce rates, have also worked to the relative disadvantage of youth. ${ }^{\mathfrak{1}}$

In this paper we take advantage of the rich micro data sets available for the U.S. and Canada to study the responses of young workcrs to the exiernal labor market forces that have affected the two countries over the past 25 years. Our key hypothesis is that young workers adjust to changes in labor market opportunities through a variety of mechanisms, including changes in living arrangements, changes in school enrollment, and changes in work effort. A comparative perspective offers at least two distinct benefits for evaluating this hypothesis. First, since the nature and timing of cyclical and secular shocks in the U.S. and Canada are slightly different, we gain valuable leverage for measuring the responses to these shocks. Second, a comparative perspective makes it immediately clear which modes of behavior are driven by country-specific policies or factors, and which are attributable to broader forces.

${ }^{1}$ Eggenbeen and Lichter (1991) conclude that changes in family structure between 1960 and 1988 account for as substantial fraction of the rise in child poverty rates in the U.S. over the period. 
The first part of the paper provides a descriptive overview of youth behavior in the two countries. Looking at such diverse oulcomes as the fraction of youth who live with their parents and the fraction who work while attending school, we find relatively similar behavior in the U.S. and Canada, with a general tendency toward convergence in outcomes over the period from 1970 to 1990 . In particular, school enrollment rates, which were traditionally lower in Canada than in the United States, are now slightly higher in Canada. Very recently, U.S.-Canadian differences have been accentuated by the prolonged and severe recession in Canada. Some differences in family structure -- associated with the higher fraction of femaleheaded families in the U.S. -- stand out. Other differences arise because the distribution of family income has been more stable in Canada, while widening sharply in the U.S. ${ }^{2}$

In the second part of the paper we develop and estimate a series of models for a variety of youth outcomes. Traditionally, economists have focussed on youth employment or unemployment. Consistent with much of the existing literature, we interpret variation in youth employment as arising mainly from the demand side. On the supply side, we shift attention to three other behavioral outcomes that provide important mechanisms for adapting to external shocks: the decision to continue living with one's parents; the decision to attend school; and the decision to receive welfare benefits. Building on a standard choice framework, we emphasize two key "exogenous" variables: the wage rate available to young workers in the local labor market; and a measure of cyclical conditions in the local labor market. We take as our unit of observation the set of individuals of a given gender and age in a specific regional

\footnotetext{
(1993).

${ }^{2}$ This observation has been made by many other researchers, e.g., Blackburn and Bloom
} 
market. This group-level analysis helps to solve a number of econometric issues (associated with the measurement of wages for non-workers) while retaining substantial variation in the exogenous variables across observations. We use a pooled data set based on six provinces/regions in Canada and nine Census divisions in the U.S. over the period from 1971 to 1994 to estimate our models.

The results of our analysis suggest that youth in the U.S. and Canada exhibit a multidimensional response to changing labor market conditions. As in most of the literature, we find that the traditional focus of economists' interest -- youth employment -- is highly responsive to local cyclical conditions but relatively insensitive to changes in wages. But other aspects of youth behavior are also affected by local labor market conditions. In particular, "home leaving" behavior and the enrollment decisions are relatively sensitive to cyclical conditions and to the relative level of youth wages.

\section{L_An_Overview_of_Youlh_Labor_Mackets and_Outcomes}

\section{a._Aggregate I abor Macket_Data}

We begin with an aggregate overview of the youth labor markets in Canada and the United States. The first three columns of Table 1 present data on the fraction of young workers in the population, the civilian labor force, and civilian employment. ${ }^{3}$ In both the U.S.

${ }^{3}$ The addition of members of the armed forces to the population and labor force has a modest effect on the trends in the data in Table 1. For example, there were roughly 500,000 fewer members of the armed forces in the U.S. in 1980 or 1990 than in 1970. Assuming that 80 percent of the difference were aged 16-24, the addition of armed forces members would raise the employment-population rate in 1970 (relative to later years) by 0.6 percentage points. 
and Canada the youth share of population peaked around 1980 and has falten steadily since then. Similar patterns hold for the labor force and for employment. A longer term perspective on the effect of the "baby boom" on employment shares is provided in Figure 1, which plots the relative size of different age groups over the period since 1950 . After a decade of stability in the 1950 s, the fraction of jobs held by youth rose by over 200 percent in both countries from 1960 to 1980 . The relative fractions of jobs held by $25-34$ and $35-44$ year old age groups follow parallel paths with 10 and 20 year lags, respectively.

Despite the relative stpply shock created by the baby boom, the economies of Canada and the U.S. were able to create jobs for young workers at a roughly comparable pace. Thus, the ratio of the employment-population rate of youth to the overall employment-population rate was constant (or even rising) in both countries over the 1970s and 1980s. Another aspect of the supply side that underlies the data in Table 1 is the rising labor force attachment of women. This phenomenon accounts for the roughly 6 percentage point rise in overall labor force participation and employment from the 1970 s to 1990 . A similar trend occurred for young women, leading to proportional shifts in the employment and participation rates of youth.

The three right-hand columns of Tabie 1 presenl data on unemployment rates. In the U.S., young workers historically have accounted for a disproportionate share of unemployment: the unemployment rate of 16-24 year oids ranges from 1.9 to 2.2 times the

The sharp decline in the relative employment share of 15-24 year old group in the 1990s in Canada is due to the recession, which led to an unprecedented drop in the employment-population rate of youlh. 
overall unemployment rate. In Canada unemployment is more evenly distributed by age: the unemployment rale of 15-24 year olds ranges from 1.6 to 1.8 times the overall rate.

Interestingly, there is little evidence of a systematic relative trend in labor market opportunities for youth over the past 25 years in either country.

Both the U.S. and Canadian economies have strong regional components that lead to differential labor market outcomes for youth in different parts of the country. ${ }^{5}$ The disparities in regional economic conditions are illustrated in Figure 2, which shows overall employmentpopulation rates and youth employment rates by province (for Canada) and by region (for the U.S.). All provinces and regions experienced a peak in employment in the late 1970s, followed by downturn in the early 1980s. The timing and strength of the subsequent recovery varies somewhat by region, with the sharpest gains in the East coast, Mid-West, and Pacific regions of the U.S., and in Ontario, Quebec and British Columbia in Canada. The subsequent recession in the early 1990s was particularly pronounced in the New England and Pacific regions of the U.S. and in the eastem and central provinces (especially Ontario) of Canada. A prominent feature of Figure 2 is the excess cyclical volatility of youth employment-population rates: national or regional fluctuations in overall einployment are typically magnified by a factor of 1.5-2.0 in youth employment. We return to a more detailed analysis of this phenomenon in Section II.

\section{b. The Relative Income Position of Youth}

\footnotetext{
'See Altonji and Ham (1990) for an interesting model of the regional components of the two economies.
} 
While the employment and unemployment data in Table 1 show little evidence of a shift in the relative economic status of North American youth, a somewhat different conclusion emerges from an analysis of family incorne. Table 2 presents data on the family income distributions and the relative position of youth in Canada and the U.S. in 1970, 1980, 1990, and 1993. We divide individuals (age 16 and more) into four quartiles on the basis of their adjusted family income. ${ }^{6}$ The upper panel of Table 2 shows the fractions of total adjusted family income received by individuals in each quartile. The table indicates that the distribution of family income has grown increasingly unequal in the U.S. while remaining stable in Canada. ${ }^{7}$

The lower panel of Table 2 shows the position of individuals age 16-24 in the quartiles of the adjusted family income distribution in the U.S. and Canada. In both countries, the fraction of youth living in families in the lowest quartile of the income distribution has risen since 1970. The rise is particularly dramatic in the U.S.: whereas 26.5 percent of youth lived

'The data for the U.S. are based on the March 1971, 1981, 1991, and 1994 Current Population Survey. The data for Canada are based on the 1971, 1981, and 1991 Census, and on the 1994 Survey of Consumer Finances (SCF). In constructing the table we use family income adjusted for family composition (i.e., family income divided by the poverty threshold income level for the appropriate family size and composition). Families are "economic" families in the CPS and the SCF (consisting of alt related people who live in the same household) but "Census" families in the Canadian Census (i.e., related subfamilies are assigned their own family income, rather than the total income of all related individuals in their household).

7As we note below, the Canadian distributional data are not strictly comparable between 1990 and 199. However, consistent data from the SCF over the 1980s and 1990s show a very stable distribution of family income in Canada (see Beach and Slotsve, 1990) over the past decade. The 1993 Canadian data are directly comparable to the 1993 U.S. data. 
in bottom quartile families in 1970, the fraction had risen to 33.9 percent by 1993 (a 28 percent increase in concentration in the bottom quartile).

By contrast, in Canada the fraction of youth living in the lowest decile only increased by 2.3 percentage points, from 24.1 percent in 1970 to 26.4 percent in 1993 . Note, however, that the distribution of family income in 1993 is not strictly comparable to other years because of data differences. Whereas family income in the 1993 SCF represents total income of the economic family, in the Census $(1970,1980$, and 1990) it represents total income of the census family. Using census family as opposed to economic family income tends to understate the position of youth in the family income distribution." To estimate the magnitude of this bias, we used the 1990 SCF to compute the fraction of youth in the lowest quartile of the distribution. In the 1990 SCF, only 25.7 percent of youth are in the lowest quartile, compared to 28.5 percent in the Census. The fraction of youth in the lowest quartile is thus overstated by 2.8 percentage points in the Census. Note, however, that even if we add this correction factor (2.8 percentage points) to the measured increase in the fraction of youth in the lowest quartile in Canada (2.3 percentage points), we still find a smaller increase in Canada ( 5.1 percentage points) than in the United States (7.4 percentage points).

In terms of relative purchasing power, the economic status of U.S. youth fell even further than suggested by their position in the relative income distribution. This is because, as shown in the upper panel of Table 2, the fraction of total adjusted income earned by first

'Since the economic family (all related people who live in the same household) is a broader concept than the census family, economic family income is more likely to include the income of the parents --which tends to improve the relative position of youth-- than census family income. See appendix 1 for more detail. 
quartile families fell by roughly 1 percentage point (a 14 percent decline) between 1970 and 1993. In Canada, on the other hand, the share of adjusted income earned by first quartile families actually rose from 1970 to 1990 .

What can explain the refative deterioration of family incomes of youth over the past two decades -- especially in the U.S.? One potential explanation is changing living arrangements: if youth who live with their parents have higher family incomes than those who live alone or head their own families, then a shift in the fraction who live with their parents would be expected to shift the relative fainily incoine status of youth. Table 3 describes the evolution of living arrangements among youth by country, year, and gender for the U.S. and Canada, while Table 4 illustrates the link between the living arrangements of youth and their family income quartile. In both of these tables, living arrangements are based on the composition of the economic family in which a young person lives. For example, a young woman who lives in the same household as her parents will be classified as "living with parents" even if she heads her own family (either as a lone mother or as a married person). Appendix 1 explains in detail how the living arrangement status was determined in the U.S. CPS and in the Canadian Census and SCF.

As shown in Table 3, the overall fraction of youth who live with their parents has risen in the U.S. and especially in Canada. Table 4 documents that in both countries, youth who live with their parents are distributed fairly evenly across the income distribution, whereas those who live alone or head their own families are disproportionately poor. Furthermore, the relative income position of youth who have left home has declined substantially between 1970 and 1993. Among youth who have left home, the fraction in the lowest quartile increases 
from 30 percent in 1970 to 50 percent in 1993 in both Canada and the U.S. Among youth who live with their parents, the fraction in the lowest quartile is stable both in the U.S. (around 25 percent) and in Canada (15-20 percent).

Taken together, these tables reveal two important conclusions. First, the deterioration in the relative family income status of youth is mostly due to a sharp fall in the relative incomes of youth who have left home. This fall is attributable in part to a rise in the fraction of youth not living with their parents who live alone or head a single-headed family (versus living with a spouse, see Table 3) and in part to a relative decline in the income of younger individuals (see Table 5 and the discussion below for more detail). Second, in the U.S. and especially in Canada, the rise in the fraclion of $16-24$ year olds who remain with their parents has forestalled a potential deterioration in the relative incomes of youth. Indeed, the simple simulation reported in the last column of Table 4 suggests that had the fraction of youth living with their parents remained at 1971 levels, the percent of youth in the bottom quartile of the family income distribution would have risen by an additional 0.9 percentage point in the U.S. (34.8-33.9) and by an additional 3.4 percentage points in Canada (29.8-26.4). In other words, the larger "move back home" in Canada has reduced the percent of youth in the bottom quartile by 2.5 percentage points.

Interestingly, we noted earlier that the percent of youth in the bottom quartile of the family income distribution rose 2.3 percentage points more in the U.S. than in Canada between 1971 and 1994, taking account of differences in the definition of family income in the SCF (1993) and the Canadian Census (1970, 1980, and 1990). Thus, if the move back 
home had not been more pronounced in Canada than in the U.S., the fraction of youth in the lowest quartile would have risen by about as nuch in the two countries.

These results suggest that in the U.S. and especially in Canada, the family has played an important role in dampening the effect of the decline in the economic status of youth. The relative expansion of this family safety net for Canadian youth is potentially surprising, given the much wider public safety net in Canada (sec e.g. Blank and Hanratty (1993)). There is certainly no indication that broader public safety net programs in Canada have "crowded out" the role of families in coping with adverse economic conditions.

\section{c_Living_Acrangements by_Gender and Age}

$\wedge$ striking feature of the data in Table 3 is the difference in living arrangements between young men and young women. In both Canada and the United States, young women are less likely to live with their parents and more likely to head their own families than young men. In part this reflects the difference in average age at marriage between men and women. In addition, the much higher fraction of women who head their own single-parent family contributes to the male-female gap in living arrangements.

A richer portrait of the changing living arrangements of youth in the two countries is provided in Figures 3 and 4 . Figure 3 shows the fraction of youth remaining with their parents, by age, for men and women in the two countries in 1971 and 1994. Almost all 16

'Note that for the U.S. we include women who have their own children but live with either or both of their parents as "living with parents" in Table 3. If these women were considered as heading their own families the fraction of single-head women would rise by about 3 percentage points in 1994. 
year-olds live with their parents. By age 19, 10-20 percent of men have left home, while 30 35 percent of women have left. Between 1971 and 1994 the most noticeable shift is the rise in the fraction of Canadian women still at home. This change was associated with a very substantial increase in school enrollment of Canadian women (see below). Close examination of Figure 3 suggests a larger average increase in the fraction of youth living with parents between 1971 and 1994 than what is reported in Table 3. A weighted average of the changes for individual age groups (with fixed 1971 weights) shows that the fraction of young men living with their parents increased by 4.9 and 9.0 percentage points in the U.S. and Canada, respectively (compared to 2.3 and 7.0 in Table 3). The corresponding numbers for young women are 6.8 and 12.7 percentage points, respectively (compared to 4.5 and 11.3 percent in Table 3). The source of discrepancy between fixed-weighted averages and the averages for all youth is the changing age distribution of youth. Since the youth population was younger -- and thus more likely to be living will parents-- ill 1971 than in 1994, the fraction of all 16-24 year olds living with their parents did not increase as much as it rose for any single-year age group (e.g. 24 year olds). Note, however, that since the changes in the age composition are very similar in the U.S. and Canada, these composition biases do not affect the relative trends in family arrangements in the two countries.

Figure 4 provides more detail on the changing living arrangements of youth by age and gender. Perhaps the most striking feature of this figure is the relatively high incidence of single motherhood among U.S. women in 1994. About 11 percent of American women age 20-24 are currently supporting a family without a male head. Even restricting attention to 
white women, 8-9 percent of U.S. women of age 20-24 were single mothers in 1994, compared to a rate of $4-5$ percent in Canada. ${ }^{10}$

The relatively lower rate of single female headship in Canada also contributes to the higher relative income status of youth in Canada. In both countries, families headed by lone mothers are very likely to be poor (Hanratty and Blank (1993)). Among lone mother heading their own households in the U.S. in 1994, for example, 89 percent were in the lowest quartile of the adjusted family income distribution. The U.S.-Canada gaps in both the fraction of young women heading lone-parent families (about 5 percent in 1994) and the fraction of youth living in single-headed families (about 10 percent in 1994) thus accounts for some of the higher relative income status of youth in Canada.

\section{d. Relative Eamings of Youth}

A second explanation for the declining relative income stalus of youth is a decline in the relative earnings of young workers. This is in fact the primary explanation for the sharp decline in relative income position of youth who live on their own. The lower panel of Table 5 shows the changing distribution of young men and women across the quartiles of the overall eamings distributions. In both Canada and the U.S., a higher fraction of youth were

\footnotetext{
We have not attempted to decompose the higher incidence of single motherhood in the U.S. into differences in out-of-wedlock births and differences in marital stability. Overall, the divorce rate is about twice as high in the U.S. as Canada. According to Vital Statistics data (e.g. Statistical_Abstract of the U.S., Table 1358), the percentage of children born to unmarried mothers was about 18 percent in the U.S. in 1980 versus 13 percent in Canada. By 1991 the rate was 30 percent in the U.S. and 29 percent in Canada. However, Vital Statistics data on marital status of mothers are not strictly comparable across countries because of differences in common-law marriage rates and other factors.
} 
concentrated in the bottom quartile of the earnings distribution in 1990 than in 1970 . The increase is more pronounced for women than for men, and greater in Canada than the United States. The greater effect for young women reflects the widening of age differentials among female workers in both countries over the 1980s. Whereas historically the wage gaps between younger and older women were much smalier than the corresponding gaps for men, over the past two decades age differentials among women have risen shapply." The greater fall in the relative eamings of young workers in Canada than the U.S. has been noted in other recent studies (e.g., DiNardo and Lemieux, 1997). Compared to the U.S., age dtfferentials among male workers rose faster in Canada over the 1980 s.

Table 5 also shows the fractions of overall eamings accruing to each of the eamings quartile in the U.S. and Canada over the past 25 years (upper panel). Among mafe workers, earnings inequality increased in both countries, while among female workers the trend was ambiguous. Taken together with the trend toward an increasing fraction of young workers in the bottom earnings quartile, however, the growth in overall earnings inequality presents at least part of the explanation for the falling relative income of youth.

Although we have treated changes in family structure and changes in the relative earnings position of youth as separate phenomena, it is possibte that family structure exerts some causal effect on earnings, or vice versa. For example, Korenman and Neumark (1991) have attempted to estimate the causal effect of marital status on male wages. While we place

\footnotetext{
"It could be argued that the rising return for labor market experience among women reflects a tendency for women to take less time off work for child-rearing, and to choose careers with greater returns to experience.
} 
no causal interpretation on the correlation between wages and family structure, for completeness we estimated a series of linear regression models to measure the wage differentials associated with three living situations: living with one's parents; living alone; and heading one's own family. The results are summarized in Appendix Table A, and are fairly similar across countries. As one might expect, young men who live alone or head their own families eam higher average hourly or weekly earnings than those who live with their parents, with a generally larger differential (10-35 percent) for those who head their own families and a smaller effect (5-20 percent) for those who live alone. ${ }^{12}$ Among young women the wage differentials associated with different living arrangements are smaller, and tend to be close to zero in more recent years.

\section{e._Work_and_School}

While economists' attention is traditionally directed toward the labor force activities of youth, school attendance is at least as important an outcome for many youth. Figure 5 presents some simple aggregate statistics on overall employment and full time enrollment rates among youth in the U.S. and Canada. ${ }^{13}$ (Full-time enrollment rates exclude individuats who

${ }^{12}$ These are estimated from linear regression models that control for age, education, race, and location, estimated by gender and country using data for log average weekly or hourly earnings in 19701980,1990 , and 1993.

${ }^{13}$ The Canadian data underlying this Fgure are for individuals age 15-24 while the U.S. data are for individuals 16-24. We have adjusted the Canadian enrollment figures to a U.S. basis assuming that 100 percent of 15 year olds are enrolled. We have not adjusted the Canadian employment rates: observe that any reasonable adjustment would raise the Canadian employment rates (by 4-5 percentage points). 
attend college part-time: total enroltment rates are about 4-5 percenlage points higher). ${ }^{14}$ In the early 1970 s, full time enroliment rates were $5-10$ percentage points higher in the U.S. than in Canada. Throughout the 1980s, however, relative enrollment rates in Canada rose, so that by 1990 the fraction of 16-24 year olds enrolled full-time in Canada actually surpassed the U.S. rate. This cross-over marks an historic turning point: throughout the 20th century the U.S. has had a much better-educaled lahor force than Canada. 's The data in Figure 5 suggest that the rankings will be reversed within the nex1 25 years.

Table 6 gives a more detailed breakdown of work and school activity rates by gender and age category over our sample period. We distinguish four types of activities: school only, work and school, work only, and "inactivity" (neither work nor school). ${ }^{16}$ Our data on school enrollment and employment for the U.S. are taken from the October CPS, and pertain to enrollment and employment as of the survey week. Our data on enrollment and employment for Canada are taken from two different sources. The rows labelled "SCF" present data from the Survey of Consumer Finances, a supplement to the Labour Force Survey much like the March CPS. Enrollment and work activities refer to the SCF survey week, in April of the corresponding year. The other rows present data from the Canadian Censuses of 1971, 1981,

${ }^{14}$ The Canadian data in Figure 5 are from published tabulations from the October LFS. The U.S. data are our own calculations using the October CPS files.

${ }^{15}$ See e.g. Freeman and Needels (1993).

${ }^{16}$ We classify as "inactive" individuals who do not actively participate to the labor narket by working or investing in human capital (going to school). Many individuals classified as "inactive" are of course actively involved in home production activities such as child-rearing. They are only inactive from a labor market point of view. 
and 1991. Enrollment in these data sources refers to school attendance at any time over the 9month period from September of the previous year to the "Census Week" (in June of the corresponding year), while work activity refers to the Census week. Complementing the data in Table 6, Figure 6 shows decompositions of work and school activities by age for U.S. and Caradian men and women in 1971 and 1994.

Among the notable features of Table 6 and Figure 6 is the rapid rise in school enrollment rates of women over the past two decades. For example, in 1981 the enrollment rate of 20-21 year women was about 30 percent in both the U.S. and Canada. By 1994 this rate was 46 percent in the U.S. and 52 percent in Canada. Coupled with this rise in school attendance (and an increase in employment rates) was a drop in inactivity rates. In 1971 over 40 percent of 23-24 year old women in the U.S. and Canada were "inactive". (Many of these were of course homemakers). By 1994 this rate had halved in both countries.

A more subtle feature of the data in Table 6 is the relative propensity of enrolled youth to work in Canada versus the U.S. For example, among 16-17 year old enrollees in 1994, 27 percent of U.S. men worked versus 33 percent of Canadian men. At higher ages, however the relative comparison was reversed. Among 23-24 year old enrollees, for example, 61 percent of U.S. men worked versus 48 percent of Canadian men. A similar paltern holds among women: in Canada, younger students are more likely to work than their U.S. counterparts, while older students are less likely to work. It is interesting to speculate as to whether this pattern is driven by the higher average cost of U.S. colleges. 
Schooling and work activity of youth are inlimately connected to their choices of living arrangements. Many youth who want to attend school full time, for example, must live with their parents, while those who want to live alone are forced to work to support themselves. In Appendix Table B we present cross-tabulations of work/school activity rates with living arrangements for men and women in 1971 and 1994 . For simplicity we limited the analysis to older youths (20-24 year olds) whose work, school, and living arrangements exhibit more variability than those of teenagers. The cross-tabulations show many of the expected patterns. For example, in both the U.S. and Canada, young men who live with their parents are more likely to be inactive, whereas young women who live with their parents are less likely to be inactive (presumably reflecting the importance of full-time home-makers in the group of women who head their own families). Interestingly, differences in school and work activity rates of young men and women who live with their parents and those who do not tended to narrow over the 1971-94 period in both countries.

\section{L.Welfare Recipiency.}

A final important determinant of the overall income status of youth is participation in government transfer programs. Table 7 gives the fractions of all youth who reported receiving "welfare" payments in the two countries, and the fractions of youth not living with the parents who reported welfare recipiency. ${ }^{17}$ The data reveal several interesting similarities and

\footnotetext{
${ }^{17}$ In our U.S. data files, welfare receipt is defined as receipt of AFDC or Public Assistance. In our Canadian SCF files for 1990 and 1993, welfare receipt is defined as receipt of Social Assistance. We do not report numbers for earlier years in Canada because of data limitations in the Canadian Census (welfare receipts cannot be distinguished from other transfers like workers'
} 
differences between the U.S. and Canada. First, in the both countries overall recipiency rates have risen over the past 25 years. Second, despite the unuch higher rale of single headship among U.S. women (see Figure 4), welfare recipiency rates are similar for women in the two countries. This presumably reflects more generous Canadian benefits, as well as the availability of Social Assistance payments in Canada to dual-headed families and individuals living alone." Third, welfare recipiency rates are much lower for young men than young women in the U.S., but only marginally lower for men than women in Canada. We believe that this reflects the much greater availability of cash welfare benefits to men in Canada than in the U.S. The major welfare benefit available to men in the U.S. (Food Stamps) are not accurately recorded in the CPS and are not included in our tabulations.

\section{II__Analytic Modelling of Youth_Behavior}

a. Theoretical Eramework

Much of economists' attention on youths has focused on the determination of employment." A conventional framework for modelling youth employment is a supplydemand model, in which wages and employment are jointly determined by demand-side factors (e.g. the state of the business cycle) and supply-side factors (e.g. the relative size of the youth population). As we have emphasized throughout this paper, however, youth behavior is

\footnotetext{
compensation in the 1981 and there is nQ information at all on transfers in the 1971 Census).

${ }^{18}$ See Blank and Hanratty (1993) and Hanratty and Blank (1992).

${ }^{19}$ See e.g. Freeman and Wise (1982). A voluminous literature focuses on the effect of minimum wages on youth employment. See Card and Krueger (1995).
} 
characterized by far more than simply holding a job. In principle, the same exogenous factors that affect employment and wages also affect other aspects of youth behavior. Thus, a natural approach to modelling the evolution of youth living arrangements, school enrollment, and program participation would be to estimate "reduced form" models, comparable to standard reduced form models for employment and wages, which show the dependence of living arrangements, enrollment, etc. on such exogenous shift factors as the state of the business cycle and the relative size of the youth population.

On the other hand, most research on youth employment in both the U.S. and Canada has (at least implicitly) assumed that minimum wages and/or other institutional features lead to above-equilibrium wages in the youth labor market. In this case, the wage is exogenous to supply-side factors and employment is delermined "on the denand curve". ${ }^{20}$ According to this view of the youth labor market, the youth wage rate and demand-side shif factors (such as the state of the business cycle) also determine other behavioral responses of youth, such as the decision to live with one's parents or the decision to altend school.

While a full investigation of the question of which (if either) of these two models of the youth labor market is correct is beyond the scope of this paper, we attempted a very simple test based on the effect of supply-shift factors on the youth wage. Specifically, we investigated the effect of changes in the relative population share of youth on the level of youth wages in different regional labor markets in the U.S. and Canada. ${ }^{21}$ Contrary to the prediction

${ }^{20}$ See e.g. Brown, Gilroy, and Kohen (1982).

${ }^{21}$ We used data for 9 regions in the U.S. and 6 provinces/regions in Canada for 1971, 1981, 1991, and 1994. In our models we regressed average wages of youth on the relative fraction of 
of an unconstrained supply-demand model, but consistent with a model in which wages are held at above equilibrium rates by minimun wage regulations or other institutional factors, we found no evidence that a larger youth population share is associated with a lower youth wage. (Indeed, our point estimates typically showed higher youth wages in regions/time periods with larger youth population shares). Based on this evidence, we decided to adopt a modelling framework in which the youth wage and the slate of demand (i.e. the business cycle) are taken as exogenous, with youth employment determined on the demand side (i.e. by employers' demand functions) and youth living arrangements, school enrollment, and program participation determined on the supply side (i.e. by individuals).

\section{b. Regional Labor.Markets}

As noted in Figure 2, labor markets in Canada and the U.S. exhibit significant regional differences. This regional variation provides a valuable tool for understanding the delerminants of youth employment and other behaviors like leaving home or deciding to enroll in school. ${ }^{n}$ For example, even in the presence of unspecified aggregate-level taste shifts, it is possible to identify the effect of changing business cycle conditions on the probability that a young person lives with his or her parents by correlating differences in living arrangements across regions with differences in local labor demand indicators. By pooling cross-sectional

the local population age $16-24$, the emplòyment-population rate of adults, region dummies, and year*country dummies.

Regional variation has been used in some studies of the effect of minimum wages: see Card and Krueger (1995). 
data for several years and including unrestricted region effects, it is also possible to account for any permanent differences in a particular outcome across different regions.

In this paper we combine region-specific data for the 9 Census divisions in the United States with data for the 6 major provinces/regions in Canada (the Atlantic Provinces, Quebec, Ontario, the Prairie Provinces, Alberta, and British Columbia). ${ }^{23}$ Our U.S. data are drawn from the 1971, 1981, 1991 and 1994 March Current Population Surveys. ${ }^{24}$ Comparable Canadian data are drawn from the 1971, 1981, 1991 Censuses and the 1994 Survey of Consumer Finances.

Table 8 provides a brief overview of the regional differences within the U.S. and Canada in three key youth outcomes: the fraction who live with their parents, the fraction employed, and the fraction enrolled in school. In both 1971 and 1994 the data for the two countries show sizeable differences across regions. For example, in 1971 the fraction of youth living with their parents ranged from 53.5 percent (Mountain region) to 72.5 percent (MidAtlantic region) in the U.S., and from 53.8 percent (Alberta) to 69.9 percent (Quebec) in Canada. ${ }^{25}$ The range of inter-regional differences in the fraction living with their parents was

\footnotetext{
${ }^{23}$ The use of regional data (as compared to state data, for example) greatly increases the number of observations for youth in each age group.

2we augment the March 1971 and 1981 data with enroliment data from the October 1970 and 1980 CPS. Beginning in the mid-1980s the March CPS contains enrollment information for youth -- thus our 1991 and 1994 enrollment data are taken from the March CPS's. A comparison of enrollment rates in the March 1991 and October 1990 CPS's reveals a high degree of consistency across regions and age groups in the two surveys.

${ }^{25}$ One possible explanation for the high employment-population ratios and the low fraction living with parents in high-growth regions like Alberta is the internal migration of young workers. It would be interesting to analyze the role of migration as another form of adjustment to changing
} 
comparable in 1994. Similarly, in 1971 the fraction of youth enrolled in school ranged from 42.7 percent (West South Central region) to 49.4 percent (Mid-Atlantic region) in the U.S., and from 45.2 percent (Quebec) to 49.7 percent (Ontario). ${ }^{26}$ Inter-segional differences in school enfollment were even wider in 1994: for example Canadian enrollment rates ranged from 47.9 percent (British Columbia) to 60.3 percent (Ontario).

A second fact revealed by the data in Table 8 is that although inter-regional differences tend to persist, they are far from permanent. In the U.S., for example, the New England and Mid-Atlantic regions had among the highest enrollment rates and fractions of youth living with their parents in both 1971 and 1994 . However, youth in the Mountain region moved from having among the lowest employment rates in 1971 to among the highest in 1994. Another remarkable change is the school enrollment rate of youth in Quebec, which moved from the lowest in Canada in 1971 to the second-highest in 1994.

\section{c_Estimation Results}

Our goal is to estimate the effects of changes in youth wages and local labor demand conditions on four youth outcomes: the probability of employment, the probability of living with one's parents, the probability of being enrolled in school, and the probability of receiving welfare payments. To analyze these outcomes we first compute the proportion $P_{n}$ of youth of

economic circumstances.

${ }^{20}$ Note that the 1971 enrollment data for Canada is defined as enrollment at any time over the 9 months prior to the Census, as compared to a "point-in-time" enrollment rate in the U.S. and for the 1994 Canadian data. 
a given age $(i=16,17, \ldots 24)$ and a given region $(j)$ and time period $(t)$ who are employed, living with their parents, enrolled, or receiving welfare. ${ }^{27}$ We then estimate "grouped linear probability models" of the form:

$$
P_{k_{k}}=\sum A_{i} Y_{1}+\sum R_{j} \alpha_{1}+\sum Y_{i} \delta_{i}+\beta_{1} W_{j}+\beta_{2} D_{k}+\epsilon_{q,}
$$

where $A_{i}$ is a set of age dummies; $R_{i}$ is a set of region dummies; $Y_{1}$ is a set of year dummies; $W_{k}$ is an index of youth wages in region $j$ and year $t$; and $D_{j}$ is a measure of local labor demand in region $\mathrm{j}$ and year $\mathrm{t}$. Note that for each region-year observation we have 9 agespecific observations on the fraction who exhibit the behavior in question. Since the key covariates -- the wage index and the labor demand index -- are the same for all age groups, and since the error terms for different age groups in the same region-year may have a shared component of variance, conventional standard errors reported for OLS estimates of (1) are likely to be biased (Moulton, 1986). We therefore report corrected standard errors which allow for an unrestricted covariance structure between observations for different age groups in the same region-year.

As an index for local labor market conditions we use the employment-population rate of 25-45 year old adults of the same gender (estimated from the same sources as the dependent variables). ${ }^{26}$ The derivation of an appropriate wage index is more difficult. For the later U.S.

${ }^{n}$ Note that employment status, living arrangements, and enrollinent are all measured as of the survey dates of the CPS, Census, or SCF, whereas welfare recipiency is measured for the previous year.

${ }^{22}$ After some experimentation, we found that the employment-population rate of 25-45 year old women was a better proxy for local labor market conditions of young women than the employment -population rate of 25-45 year old men. 
data (1981, 1991 and 1994), it is possible to use reported annual earnings, reported weeks of work, and reported hours per week over the previous calendar year to construct a measure of average hourly eamings of employed youth. However, neither the 1971 CPS nor the Canadian Census files contain direct measures of hours per week in the previous year, and both the 1971 CPS and the 1971 and 1981 Canadian Census files include only a categorical measure of weeks worked in the previous year. Thus, a direct measure of the hourly wage cannot be computed from these data sets. For each year and each gender, we therefore computed a regional wage index for youth by running a regression of log annual earnings on a standard set of demographic variables, a set of controls for weeks worked last year and hours worked in the survey week, and a set of region dummies. ${ }^{29}$ Our regional wage index is simply the coefficient on the corresponding region dummy from this regression.

In Appendix Figure 1, we plot the values of the wage index in each region for young men and young women. In this figure, the wage index is expressed in terms of deviations from the annual mean for each gender in each country. One noticeable pattern is how the real price of oil (which increased sharply in the 1970s and then declined in the 1980s) drives relative youth wages in the oil-rich regions of Canada (Alberta) and the U.S. (West South

\footnotetext{
${ }^{29}$ The control variables are a set of age dummies, years of education, and years of education interacted with age. The weeks and hours variables for Canada are a set of 5 dummies for categories of "weeks worked last year" fully interacted with a dummy for part-time/full-time status last year and a set of 8 dummies for categories of "hours worked last week". These hours variables are used because they are the broadest set that can be constructed on a comparable basis across years. A similar approach is used with the U.S. data. Note that the wage regressions are estimated using observations on youth (age 16-24 in the survey month) who reported positive earnings and positive weeks of work in the previous calendar year. (Individuals who worked last year but not during the survey week are used in the estimation).
} 
Central). One can also see how the "Massachusetts Miracle" pushed up youth wages in New England in the 1980s after these wages had declined sharply in the 1970s.

A final issue concerns the functional form of equation (1). As written, this equation implies that changes in the key covariates -- the wage index and the local demand index -exert the same effects on the probabilities of a given outcome for all 9 individual age groups. Since younger individuals have very high enrollment rates and very high rates of living with their parents (close to 100 percent for 16-year olds) this specification is clearly inappropriate. One possibility would be to use the log-odds of different outcomes as the dependent variables. As an alternative, we actually estimated an interacted version of (1), including both the levels of the wage and local demand indexes, and their interactions with the age of the specific subgroup. This specification allows the effects of higher adult employment rate, for example, to exert a systematically larger effect on the enrollment rates of older than younger individuals.

Estimation results for this interacted version of equation (1) are reported in Table 9. For simplicity, we report the effects of the two key covariates on 20 -year olds. The first part of the table show results for men while the second part shows results for women. For both genders, we report three sets of estimates: estimates for U.S. data alone; estimates for Canadian data alone; and estimates from a pooled U.S./Canada sample. In the latter case, we include country-specific year dummies, as well as region dummies for each of the 15 "regions" in the combined two-country sample. The estimates are derived from a weighted OLS 
procedure, using as a weight for each region-year-age observation the estimated population of individuals of that age in the region in that year. ${ }^{30}$

The results in the first part of Table 9 indicate that, as expected, a rise in the employment-population ratio of prime-age males has a strong positive effect on the employment rate of young men in the same region. The estimated coefficient in both the U.S. and Canada is larger than one, indicating that the employment rate of young men is more cyclical than the employment rate of prime-age males. Improving local demand conditions also tend to lower both the probability of staying at home and the probability of attending school among young men in the two countries. The cyclical effect on "staying at home" is larger in Canada while the cyclical effect on "going lo school" is larger in the United States. The estimated effects of improving cyclical conditions on the probability of welfare receipt vary by country, although in the pooled model (as in the U.S.) better local demand leads to a modest fall in welfare recipiency among young men. The positive and significant effect of local demand on welfare recipiency of Canadian men is an anomaly. It should be noted, however, that because of data limitations, comparable welfare recipiency rates are only available for the last two years of our sample period for Canada. Thus the welfare recipiency model for Canada is fit with only 12 observations on the underlying regional data.

The estimated effects of the wage index in the first part of Table 9 are quite interesting. In the employment models in column (2), wages exert essentially no effect. It should be noted that these estimated wage coefficients may be upward-biased by unobserved region-specific

\footnotetext{
${ }^{30}$ In the pooled models, we multiply the weighted number of individuals in Canada by ten to give a relatively similar weight to the two countries in the regressions.
} 
factors that lead to higher employment demand for youth and at the same tine exert upward pressure on youth wages. We attempted to instrument the youth wage using the fraction of youth in the regional population (a "supply-shift" variable) but as noted earlier this variable has an insignificant (and "wrong-signed") effect on wage levels in the first-stage equation. In future work it would be interesting to evaluate the performance of other potential instruments, such as a minimum wage measure.

In contrast to the negligible effect of the wage index on employment, the estimates in Table 9 suggest that higher wages exert a more systematic effect on the living arrangements and enrollment behavior of young men. In particular, rising wages are associated with a lower probability of living with one's parents, and a lower probability of enroliment. Both effects are marginally significant in the country-specific models and in the pooled model. Overall, the results in Table 9 suggest that external labor market conditions exert a fairly strong effect on a wide range of behaviors of young men. In regions with stronger local demand conditions and higher wages, young men are more likely to work, more likely to strike out on their own and move away from their parents' home, and less likely to go to school. In regions with depressed local demand conditions and lower wages, young men adapt by continuing to live with their parents and by attending school. The latter mechanism leads to an interesting paradox: a depressed labor market may lead to greater human capital accumulation and (presumably) to enhanced long-run growth.

In comparison to the results for men, the results for women in the second part of Table 9 are more variable across countries. The employment modeis (in column 2 ) show that young women's employment is less responsive to changes in the prime-age adult employment rate 
(the employment rate of adult women in this case) than the employment of young men. There is no indication that higher wages lower young women's employment. Better cyclical conditions (as measured by the employment rate of prime-age women) exert a strong negative effect on the probability of living at home among Canadian women, but only show a weak negative effect among U.S. women. Perhaps surprisingly, the estimated cyclical effects on enrollment are positive (but only significant in the U.S.) for the two countries.

As in the case of men, the estimates suggest that higher wages exert a systematic effect on the living arrangements and enrollment behavior of young women. In particular, rising wages are associated with a lower probability of living with one's parents, and a lower probability of enrollment. Both effects are statistically significant in the country-specific models and in the pooled model.

The cyclical effects on welfare recipiency in the U.S. are relatively strong but for Canada are again "wrong signed", perhaps as a consequence of the limited amount of data used in the Canadian welfare models. On the other hand, the wage has a negative and significant impact on welfare recipiency in Canada, as expected.

Overall, the estimation results are fairly similar for young men and young women. Looking at the pooled models for outcomes other than welfare recipiency, the only systematic difference between men and women is that the employment-population rate of prime age adults has a negative and significant effect on the probability of attending school for young men, but a positive and insignificant effect for young women. Alt the other estimated effects conform to our expectations, except perhaps for the effect of the wage on employment which should be negative when wages move employment along a fixed demand curve. 


\section{d.Are USS_Canada_Differences_in_Youth_Outcomes_Driven by_Regional_Labor_Markels?}

The results presented in Table 9 suggest that the state of the regional labor market has important influences on youth decisions to stay at home, work, or enroll in school. We now turn to the question of whether changing regional labor market performance can account for differential U.S.-Canada trends in these outcomes over the last 25 years.

Table 10 shows the changes in the U.S.-Canada gaps in each "outcome" from 1971 to 1991 and from 1991 to 1994 , along with the changes in each outcome predicted by our model as a consequence of changing regional labor market conditions, and the "residual" component." To measure the total changes and predicted changes in each outcome we fit pooled models for the 6 Canadian provinces and 9 U.S. regions using a full set of countryspecific year effects. In the first specification we excluded the regional labor market variables (the wage index and the adult employment rate), while in the second specification these variables were included. The total changes are measured by the differences in the differences of the U.S. and Canadian year effects between the base year and the end year (e.g. 1971 and 1991 ) in the model that excludes the labor market variables. The unexplained changes are measured by the differences in the differences between the base year and the end year in the model that includes the labor market variables. Finally, the explained changes are measured by the differences between the total and unexplained changes.

\footnotetext{
${ }^{31}$ Note that our regional wage indexes have the same mean in every year. By construction, then, the average changes in the wage index variable over time are 0 for both country, and this variable cannot "explain" any relative trends between the two countries.
} 
Panel A of Table 10 indicates that, for both men and women, the proportion of youth living with their parents and the proportion of youth working evolved similarly in the two countries between 1971 and 1991 . By contrast, the proportion of youth attending school increased much faster (10 percentage points more) in Canada than in the U.S. In the case of men, the slightly better labor market conditions in Canada account for a small increase in the probability of working and a small decrease in the probability of living with parents. Note that these effects are substantially larger for women. This is due to the fact - not shown in the tables -- that the employment rate of adult women increased substantially more in Canada than in the U.S during this period.

Note also that labor markel conditions do nol account for any of the relative growth in the fraction of young Canadians enrolled in school. If anything, slightly better labor market conditions should have reduced this proportion in Canada relative to the U.S. Overall, none of the relative changes in aggregate youth outcomes between the U.S. and Canada between 1971 and 1991 are explained by our labor market variables.

By contrast, Panel B shows that the poor performance of the Canadian labor market between 1991 and 1994 fully explains of the "move back home" of young Canadians. For both men and women, the proportion of youth living with their parents increased by about 3 percentage points more in Canada than in the U.S. (row 1), which corresponds to the change predicted by the relative deterioration of the Canadian labor market (row 2). Similarly, the sharp drop in the relative employment rate of young Canadians is explained by the poor labor 
market conditions in Canada. ${ }^{32}$ If anything, in fact, the employment rate of young men in Canada should have dropped slightly more than it actually did. The proportion of young Canadian men attending school also increased less than predicted between 1991 and 1994. Changing labor market conditions should have pushed up the enrollment rate by 2.7 percentage points more in Canada than in the U.S., while the actual rate only increased by 1 percentage point. In the case of women, there was no substantial change (actual or predicted) in enrollment rates in Canada relative to the U.S.

Overall, our findings suggest that young Canadians have adjusted to the poor conditions of the Canadian labor market during the 1990 s by staying with their parents longer (and working less). By contrast, labor market conditions explain little of the sharp increase in enrollment rates in Canada relative to the U.S. between 1971 and 1991. The explanation for this increase has to be found elsewhere. One conjecture is that Canadian youth were simply catching up to American youth through the 1970s and 1980s. Lower tuition costs in Canada may also explain some of the change.

\section{Conclusions}

In this paper we take advantage of the rich micro data sets available for the U.S. and Canada to study the responses of young workers to the external labor market forces that have

${ }^{32}$ In Canada, there is a spurious negative trend in the proportion of youth working or attending school because of changes in the definition of these variables between 1991 (Census) and 1994 (SCF). The numbers reported in Panel B of Table 10 have been adjusted using an adjustment factor computed by comparing employment rate and the enrollment rate in the 1991 SCF and the 1991 Census. The adjustment factor is 5.4 percentage points for employment and 7.1 percentage points for school enrollment. 
affected the two countries over the past 25 years. Our key hypothesis is that young workers adjust to changes in labor nuarket opportunities through a variety of mechanisms, including changes in living arrangements, changes in school enrollment, and changes in work effort.

In the case of young men, the results support this hypothesis. In regions with stronger local demand conditions and higher wages, young men are more likely to work, more likely to strike out on their own and move away from their parents' home, and less likely to go to school. In regions with depressed local demand conditions and lower wages, young men adapt by continuing to live with their parents and by altending school. The results for young women are similar except that local demand conditions (the employment-population rate of adult women) have no significant effect on school enrollment.

In fact, poor labor market conditions in Canada explain why the fraction of youth living with their parents has increased in Canada relative to the U.S. recently. Paradoxically, this move back home also explains why the relative position of Canadian youth in the distribution of family income did not deteriorate as fast as in the U.S. Other factors like the relatively high rate of single-headed households in the U.S. also have a negative impact on the relative income position of U.S. youth. However, unlike the move back home in Canada which is a recent phenomenon, the high incidence of single-headed households in the U.S relative to Canada has persisted throughout the period considered here (1970 to 1994). Shortrun factors like the state of the labor market cannot account for the permanent difference in the fraction of youth who live in single-headed households in Canada and the U.S.

The descriptive analysis presented in this paper raises a number of other interesting issues for future research. For example, enrollment rates were traditionally higher in the U.S. 
than Canada but the situation has been reversed in the early 1990s. It would be interesting to know whether differences in college and university tuition levels and student loan programs can explain this reversal of historic trends. It would also be interesting to explore what analytical models of family behavior are consistent with our empirical observation that the family acts as a "safety net" for young people during difficult economic times. 
Appendix 1: Determinalion of Living Arrangements.

\section{US Data}

We used the household and family relationship variables in the Current Population Survey (CPS) to distinguish between three living arrangements: living with one's parents; living outside one's parent's home as a head (or wife) of one's own family; and living outside one's parent's home as a lone individual (with or without roommates). Individuals who head their own family but live with their parents (or parents-in-law) are considered to be living with their parents. In addition, individuals who live with some other relative (e.g. a grandmother or aunt) with or without their own family are classified as living with their "parents".

Individuals who head their own family but live with their parents (or parents-in-law) are classified as living in related subfamilies in the March CPS. For these individuals (and their children) we used the family information for the associated primary family to determine whether the parental family has dual heads, a single female head, or a single male head. For all other individuals we used the family information for their own family to determine whether the family has dual heads, a single female head, or a single male head.

Specific details for the various CPS surveys are as follows:

March_1971

We use "family relationship summary" (columns $43-44$ of the person record) to delermine living arrangements. This variable combines primary and related subfamilies.

Individuals coded as children, grandchildren, or other relatives of the head (codes 3-9) are classified as living with their parents. Individuals coded as not in a family (codes 10-11) 
are classified as living alone. Individuals coded as heads or wives (codes 1-2) are classified as heading their own family.

March_1981

We use "relationship to householder" (column 103 of the person record) plus "subfamily relationship" (column 106 of the person record) to determine living arrangements. Individuals whose relationship to householder is child or other relative (column $103=4-5$ ) plus individuals who are unrelated subfamily members (column $103=6$ ) and whose subfamily relationship is child or other relative (column $106=3-4$ ) are classified as living with their parents. Individuals who are non-family householders or unrelated individuals (column $103=2,7$ ) are classified as living alone. Individuals whose relationship to householder is householder or spouse (column $103=1,3$ ) plus individuals who are unrelated subfamily members (column $103=6$ ) and whose subfamily relationship is reference person or spouse (column $106=1,3$ ) are classified as heading their own families.

\section{March 1991, March 1994}

We use "family type" (column 31 of the person record) plus "family relationship" (column 32 of the person record) to determine living arrangements. Individuals whose family type is primary family or unrelated subfamily (column $31=1$ or 4 ) and whose family relationship is child or other relative (column $32=3-4$ ) plus individuals whose family type is related subfamily (column $31=3$ ) are classified as living with their parents. Individuals whose family type is non-family householder or secondary individual (column $31=2$ or 5 ) are 
classified as living alone. Individuals whose family type is primary family or unrelated subfamily (column $31=1$ or 4 ) and whose family relationship is reference person or spouse (column $32=1-2$ ) are classified as heading their own families.

\section{Canadian Data}

1971,1981 , and 1991. Census.

In the Canadian Census (1971, 1981, and 1991), we use the variables "census family status" and "relationship with the head of household" to determine the same type of family arrangements as in the U.S. data. We classify as "living with parents" all individuals whose census family status is "child". By definition, these individuals live with their parents, have never been married, and have no children. We also classify as "living with parents" some individuals whose relationship with the head of household is "child" or "child-in-law" but who are not themselves children a census family. Most of these individuals are either "heads" (husband or single parent) or "wives" of their own census family who happen to live with their parents or in-laws. We also classify as "living with parents" few individuals who are "child" or "child-in-law" of the head of household but whose census family status is "non-census family member living with relatives". Examples of these cases would be a divorced daughter living with her parents or a widower living with his in-laws.

Among individuals who were not classified as "living with parents", we classify as "living outside one's parent's home as a head (or wife) of one's own family" those who are a head (or wife) of a census family. All other individuals do not live in a census family and are classified as "living outside one's parent's home as a lone individual (with or without 
roommates)". In the 1981 and the 1991 Census, the "census family status" can also be used to find out whether a child in a census family lives in single- ò dual-headed family. Since no such information is available for other individuals classified as "living with parents", we assume that all these individuals live in dual-headed households. This assumption is innocuous since only about 2 percent of individuals classified as "living with parents" are not a child in a census family. The "census family status" variable can also be directly used to classify individuals who are the head of their own family as. "head of a dual-parent family" or "head of a single-parent family".

In the 1971 Census, however, the "census family status" variable provides no information on whether a family is single- or dual-headed. This explains why the subcategories that refer to living with parents in a single- or dual headed family are left blank in Tabie 3 in 1971 . On the other hand, we use the martial status variable to classify as "single parent" an individual who is the head of a census family and is not married.

\section{Survey of Consumer Finances}

In the 1994 SCF, we used three variables --census family status, economic family status, and family type-- to determine the living arrangements of individuals. We classify all individuals whose economic family status is "child or child-in-law" as "living with parents". We also classify as "living with parents" individuals who are neither head, spouse, or child/child-in-law in an economic family (the residual calegory "other" in the SCF) and are 
also in the "other" category for census family status. ${ }^{33}$ A son living with his mother and his grand-father (head of the economic family) would fall into this particular category.

Individuals not classified as "living with parents" are classified are head or spouse of their own family when the census family status is "head" of "spouse". Individuals in the census family category "not in census family or lone parent" are classified as head of their own (single-headed) family when the "family type" variable indicates that they live in a lone parent household. All other individuals are classified as "living alone". Finally, the "family type" variable is also used to determine whether individuals who live with their parents live in a single- or a dual-headed family.

${ }^{33}$ There are four possible categories for the census status variable: "head", "spouse", "not in a census family or lone parent", and "other". Logically, all individuals in the "other" category should be children in a census family but few of them ( 0.21 percent of the sample) are also classified as head of an economic family. We classified this latter group of individuals as "living alone". 


\section{REFERENCES}

Altonji, Joseph G., and John C. Ham. "Variation in Employment Growth in Canada: The Role of External, National, Regional, and Industrial Factors," Iournal of Labor Fconomics 8 (January 1990): \$198-\$236.

Beach, Charles M., and George A. Slotsve. Are We Becoming Two Societies?: Income Polarization and the Myth of the Declining Middie Class in Canada. Toronto: C.D. Howe Institute, 1996.

Blackburn, McKinley L., and David E. Bloom. "The Distribution of Family Income: Measuring and Explaining Changes in the 1980s for Canada and the United States," in D. Card and R. Freeman (eds.) Small Diffenences that Matter: Labor Markets and Income Mainlenance in Canada and the United States. Chicago: University of Chicago Press, 1993, pp. 233-266.

Blank, Rebecca M. and Maria J. Hanratty. "Responding to Need: A Comparison of Social Safety Nets in Canada and the United States," in D. Card and R. Freeman (eds.) Small.Differences that Matter. Lahor_Markets_and_Income_Maintenance in_Canada_and the_Uniled_States. Chicago: University of Chicago Press, 1993, pp. 191-232.

Brown, Charles, Curtis Gilroy, and Andrew Kohen. "The Effect of the Minimum Wage on Employment and Unemployment," JournaLof_Economic_Literature_20 (June 1982): 487-528

Card, David and Alan B. Krueger. Myth_and Measurement: The New Economics of the Minimum Wage. Princeton NJ: Princeton University Press, 1995.

DiNardo, John, and Thomas Lemieux. "Diverging Male Wage Inequality in the United States and Canada, 1981-1988: Do Institutions Explain the Difference?" forthcoming in the Industrial and Labor Relations Review, July 1997.

Eggenbeen, David J. and Daniel T. Lichter. "Race, Family Structure, and Changing Poverty Among American Children". American Sociological Review 56 (December 1991): 801-817.

Freeman, Richard B., and Karen Needels. "Skill Differentials in Canada in an Era of Rising Labor Market Inequality," in D. Card and R. Freeman (eds.) Small_Differences_that Matler: Labor_Markets.and_Income_Mainlenance'.in Canada and_the_United_States. Chicago: University of Chicago Press, 1993, pp. 45-67.

Freeman, Richard B. and David A. Wise. The_Youth_Labor Market Problem - its Nature, Causes, and Consequences. Chicago: University of Chicago Press, 1982. 
Hanratty, Maria J. and Rebecca M. Blank. "Down and Out in North America: Recent Trends in Poverty Rates in the U.S. and Canada," Quarterly Journal of Economics 107 (February 1992): 233-54.

Korenman, Sanders, and David Neumark. "Does Marriage Realiy Make Men More Productive?" Journal of Human Resources 26, (Spring 1991): 282-307.

Levy, Frank and Richard J. Mumane. "U.S. Earnings Levels and Earnings Inequality: A Review of Recent Trends and Propose Explanations." Iouraal of Economic Literature 30 (1992): 13331381.

Moulton, Brent. "Random Group Effects and the Precision of Regression Estimates," Inural of Econometrics 32 (1986): 385-397. 
Figure 1: Effect of Baby Boom on Employment by Age

\section{Relative Size of Age Cohorts Uniled States}

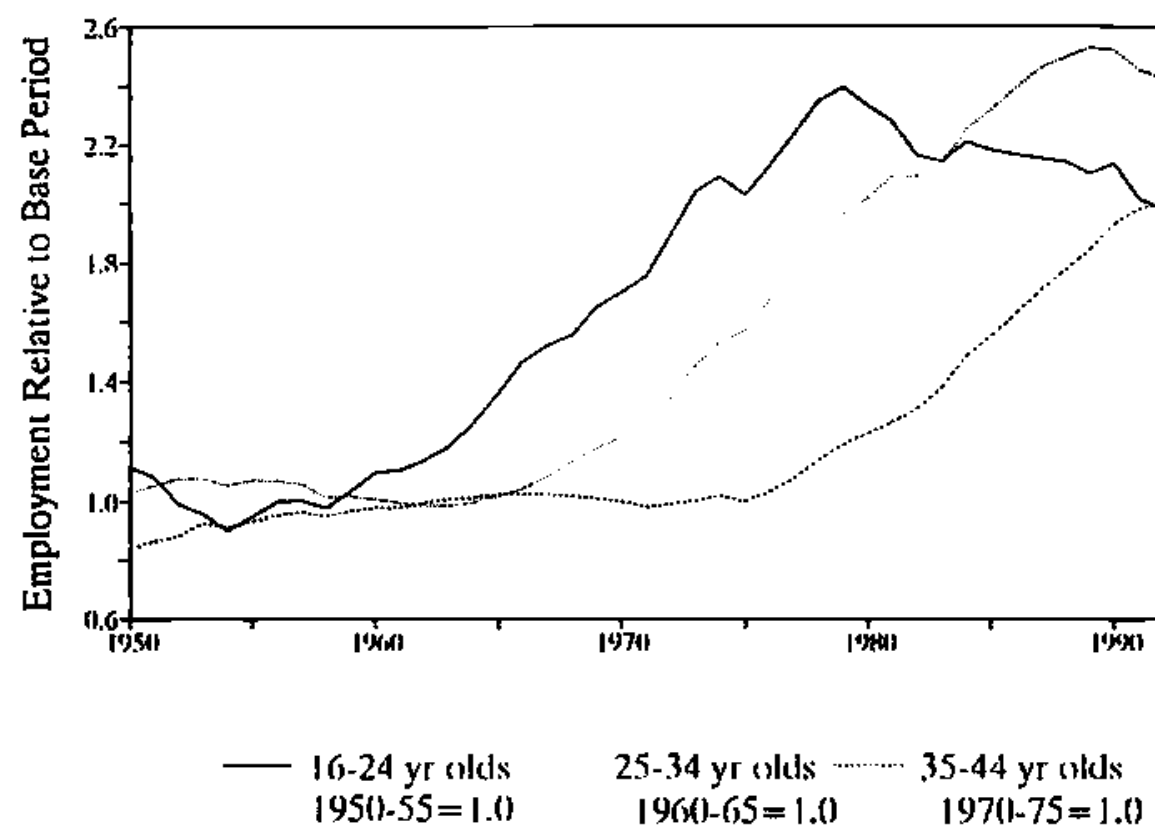

\section{Relative Size of Age Cohorts}

Canada

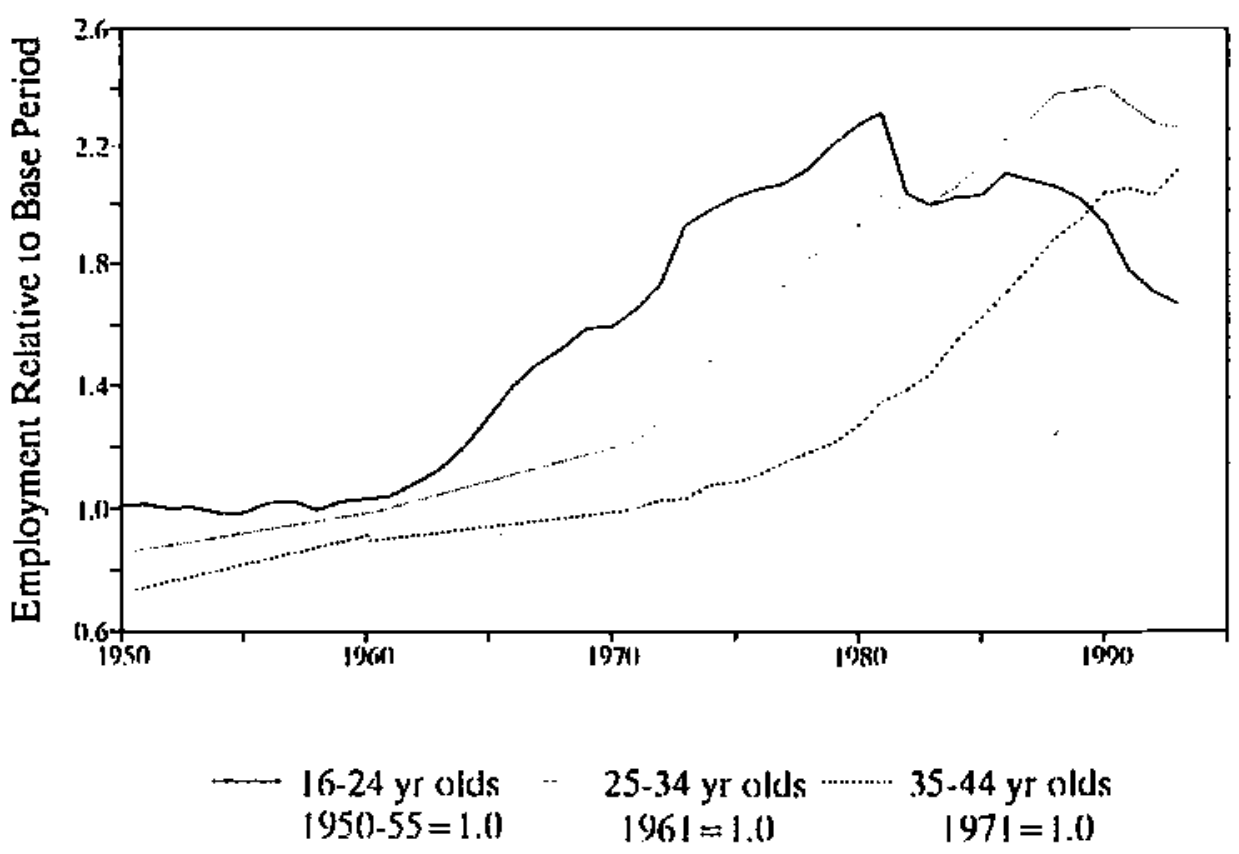


Maritimes
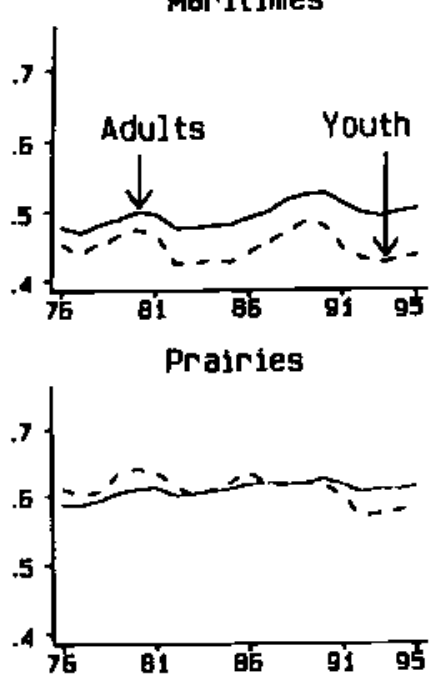

New England

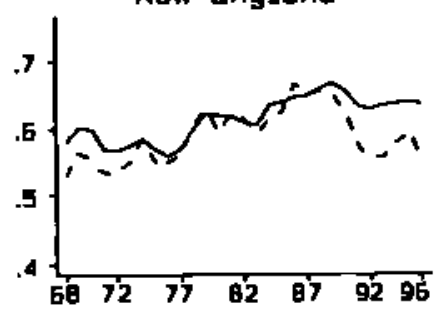

West North Central
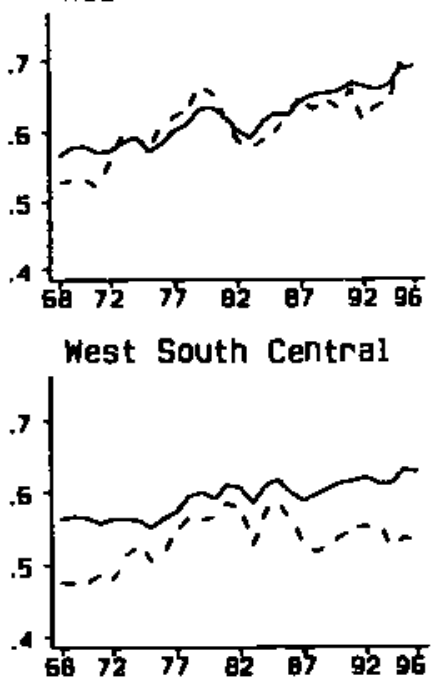

Quebec
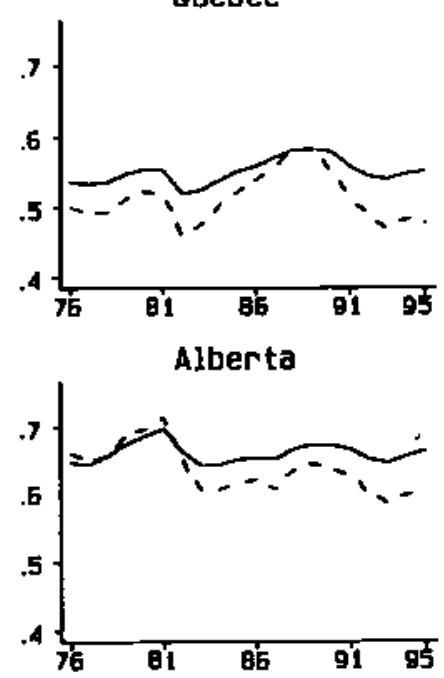

Middle Atlantic

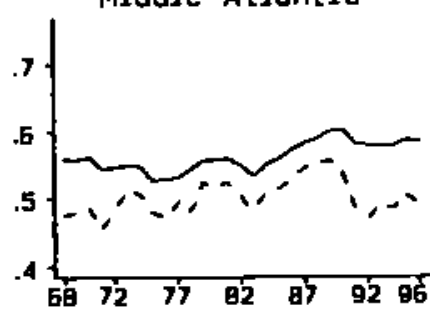

South Atlantic
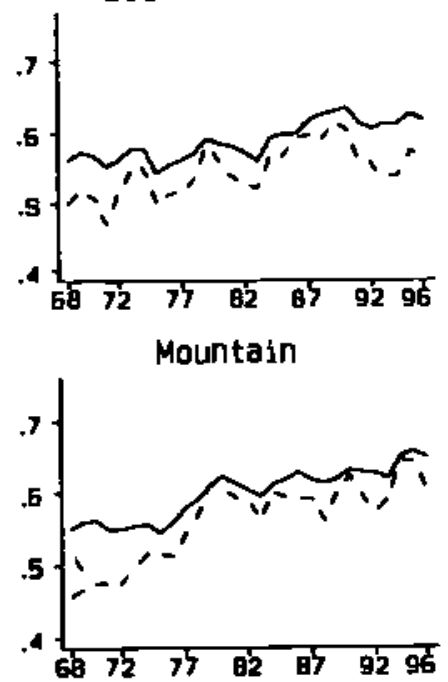

Ontario
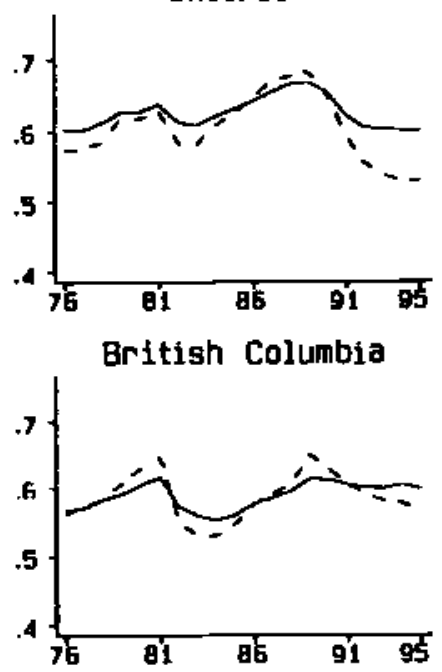

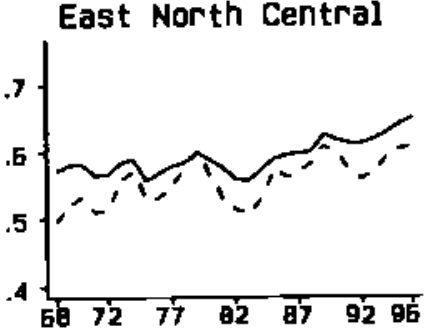

East South Central

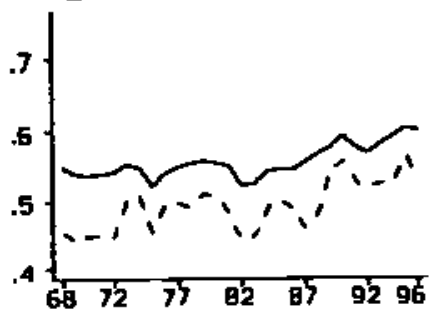

Pacific

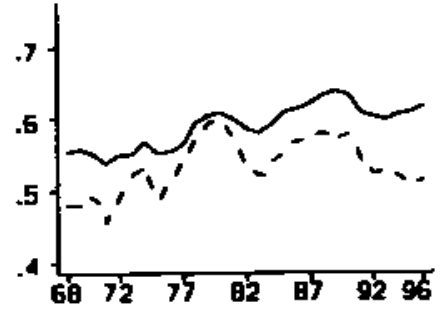

Figure 2: Regional Variation in Employment 
Figure 3: Fractions of Youth Living with Parents by Age

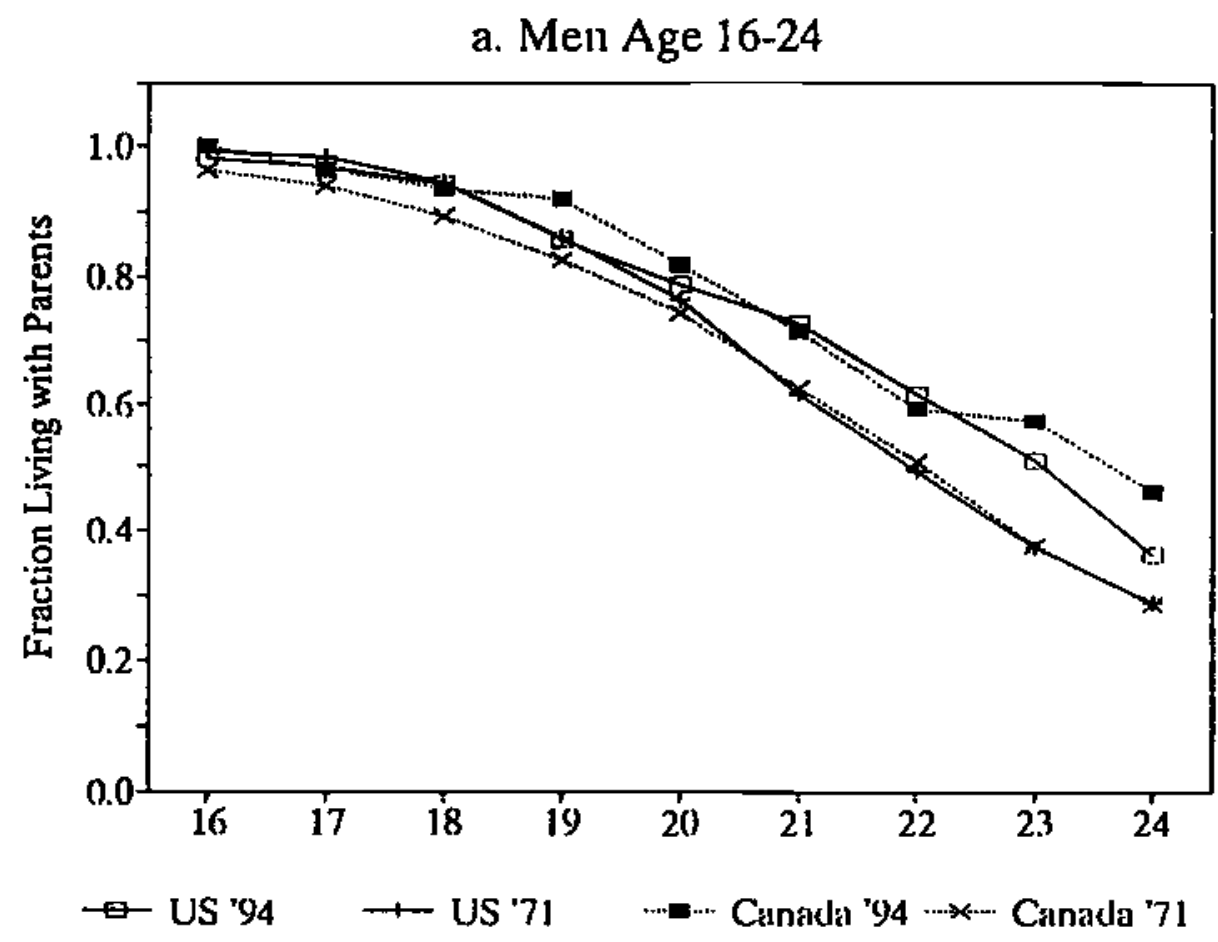

b. Women Age 16-24

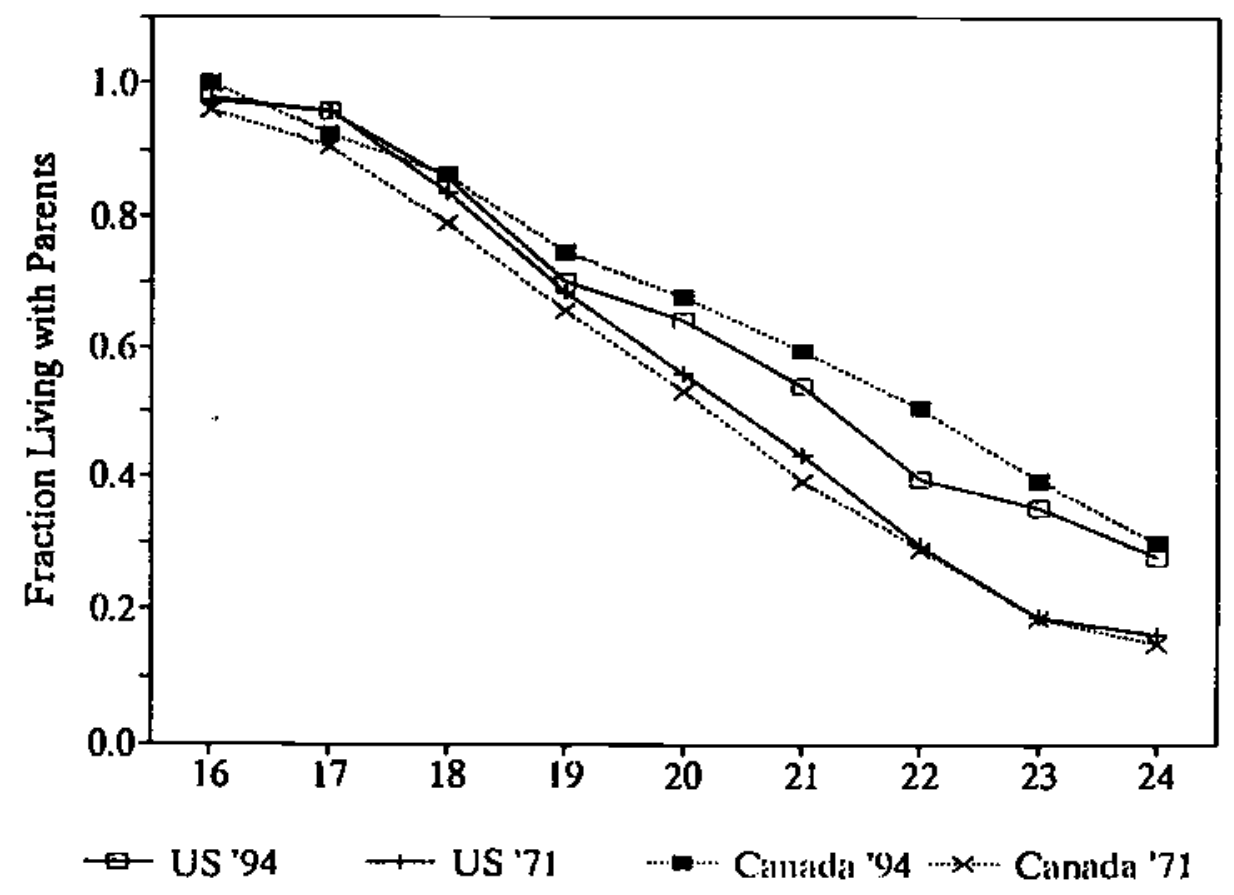



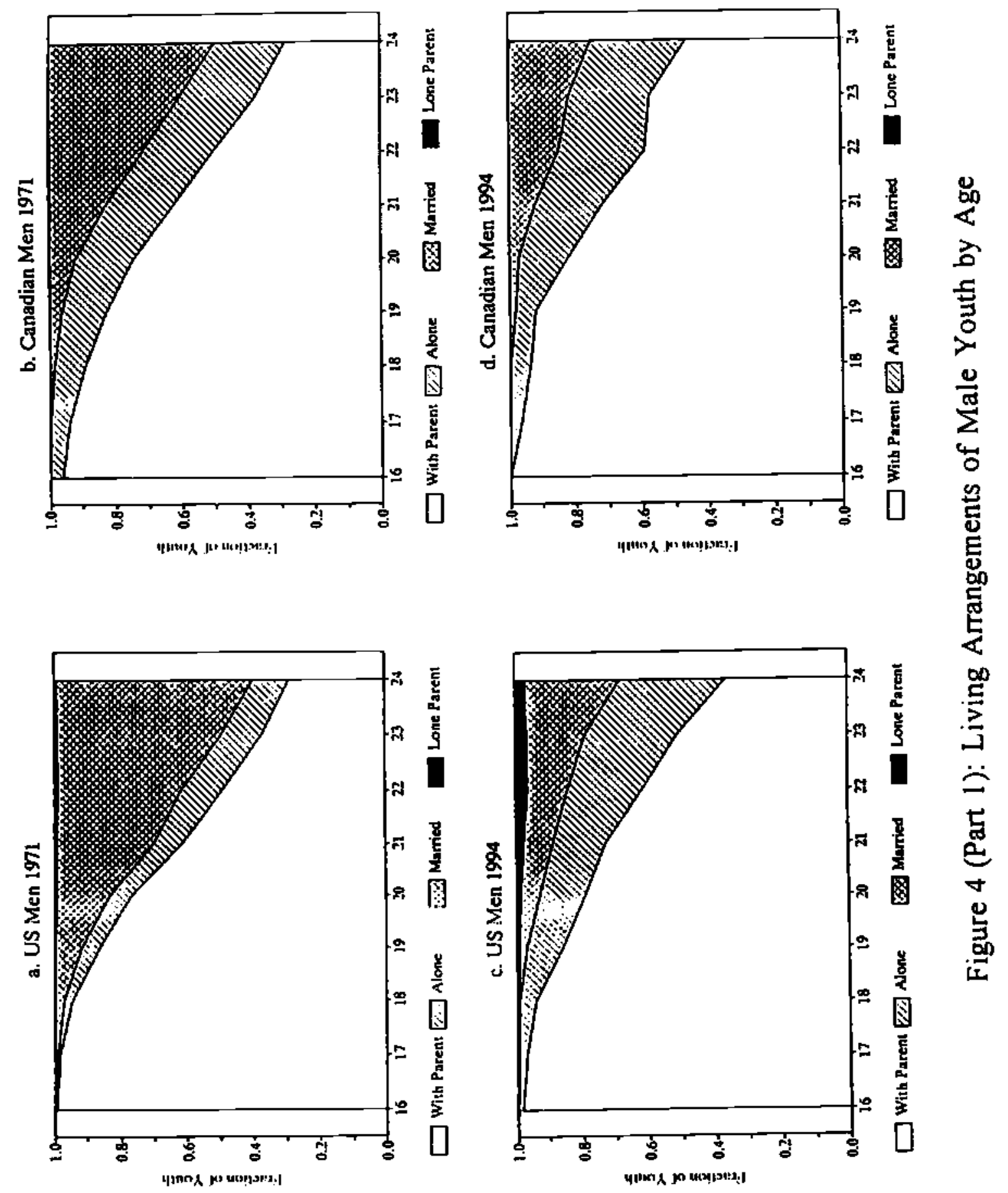

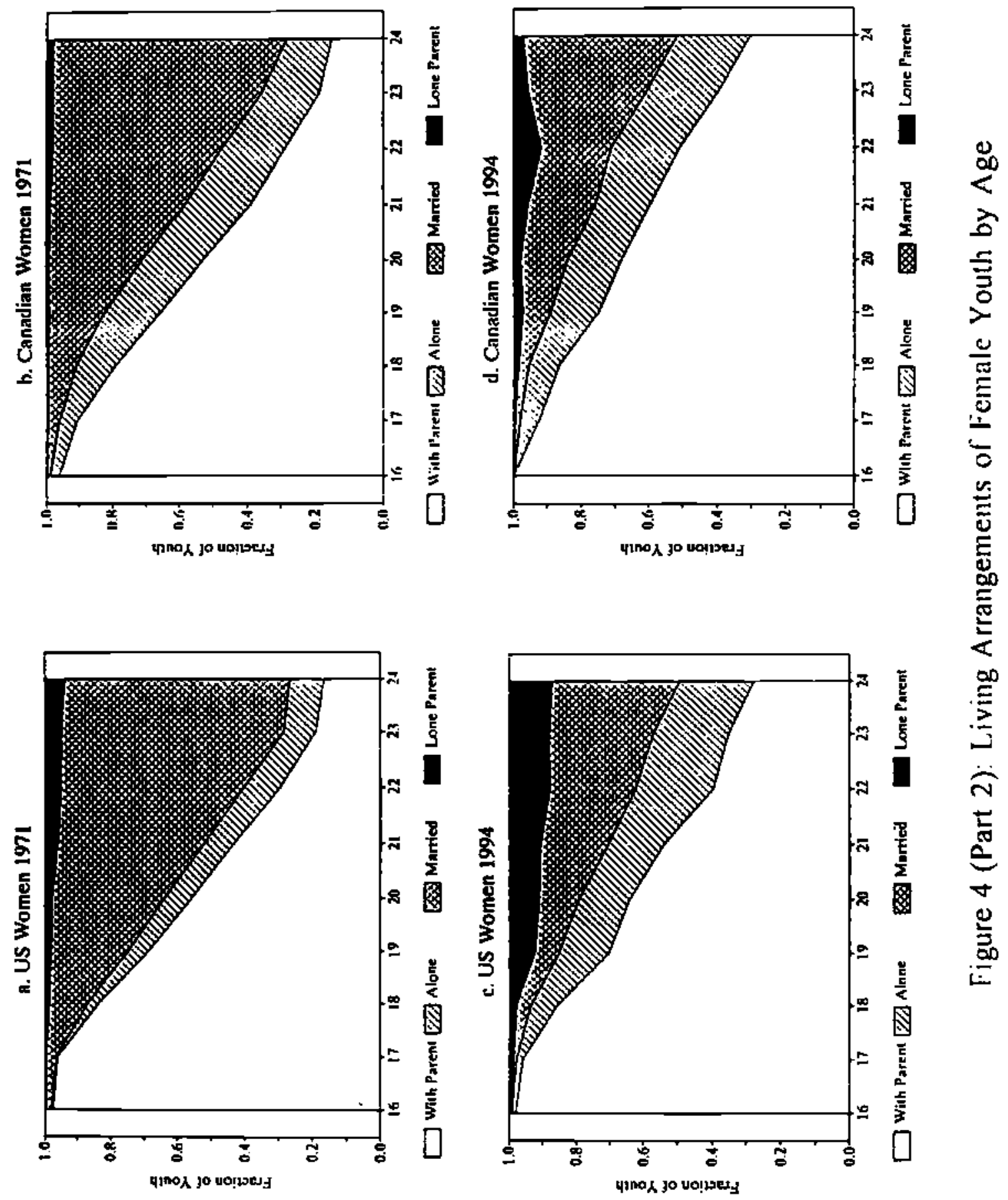
Figure 5:

Employment-Population Rate and Full-time Enrollment Rate of Youth

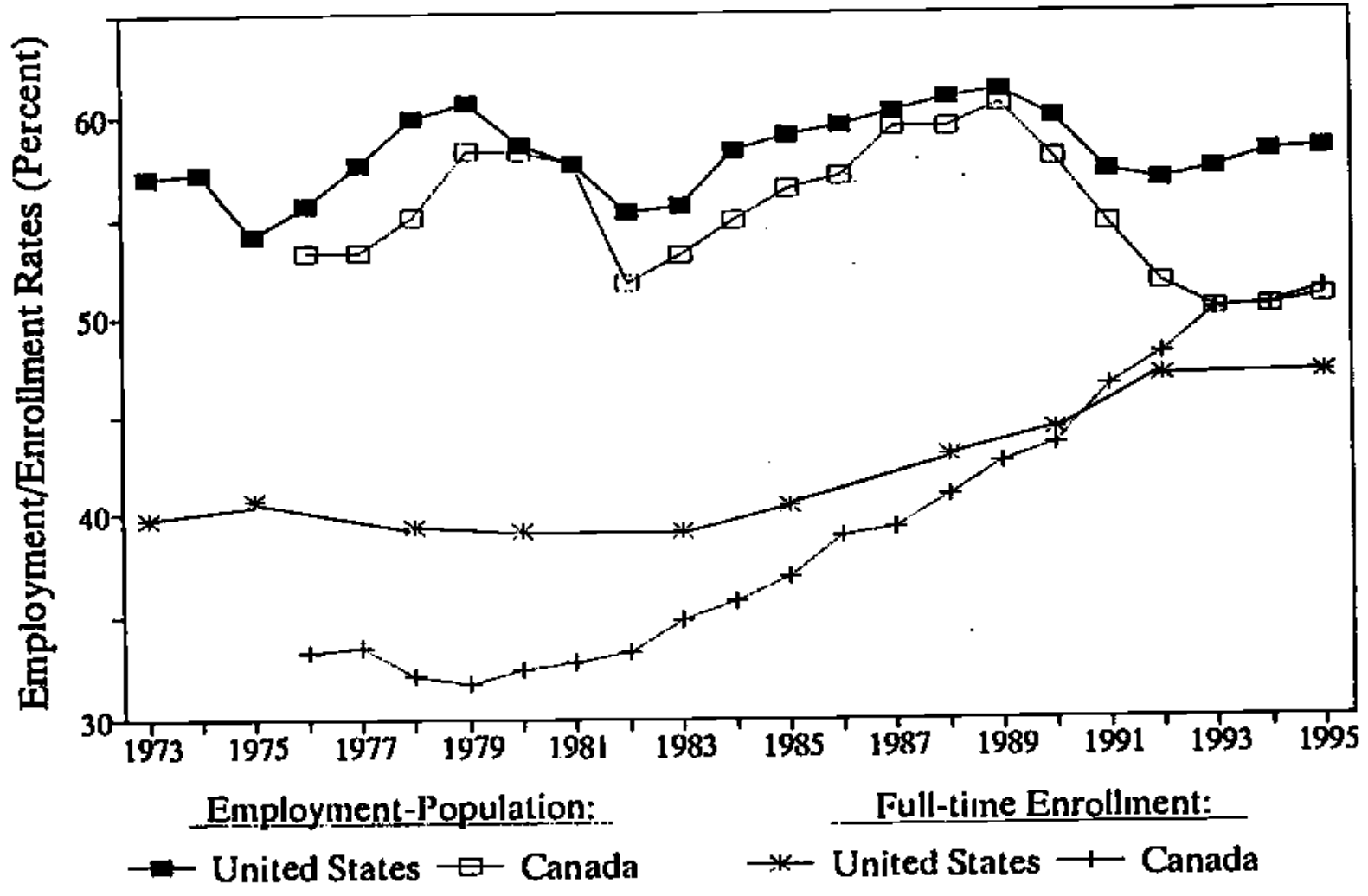




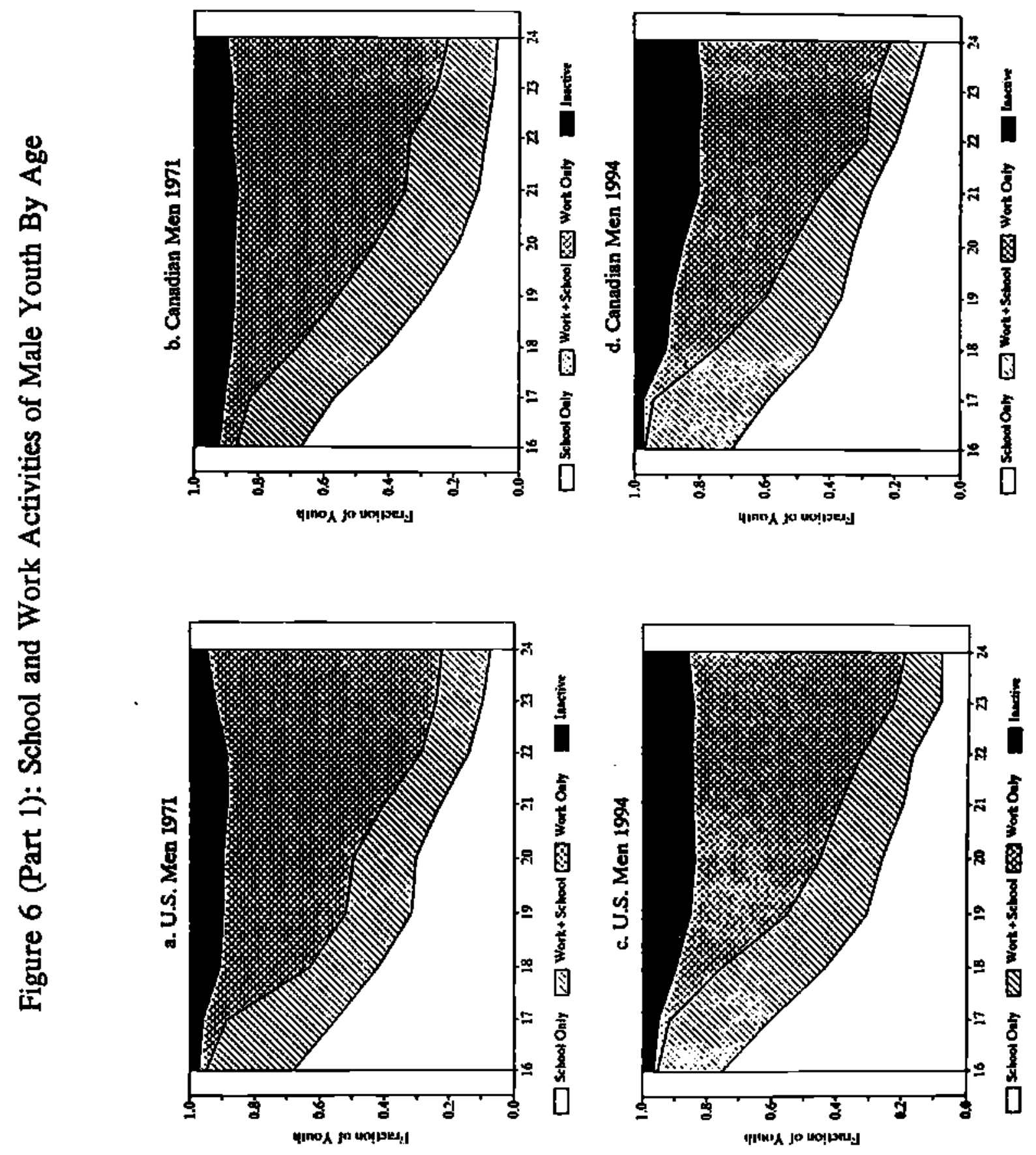




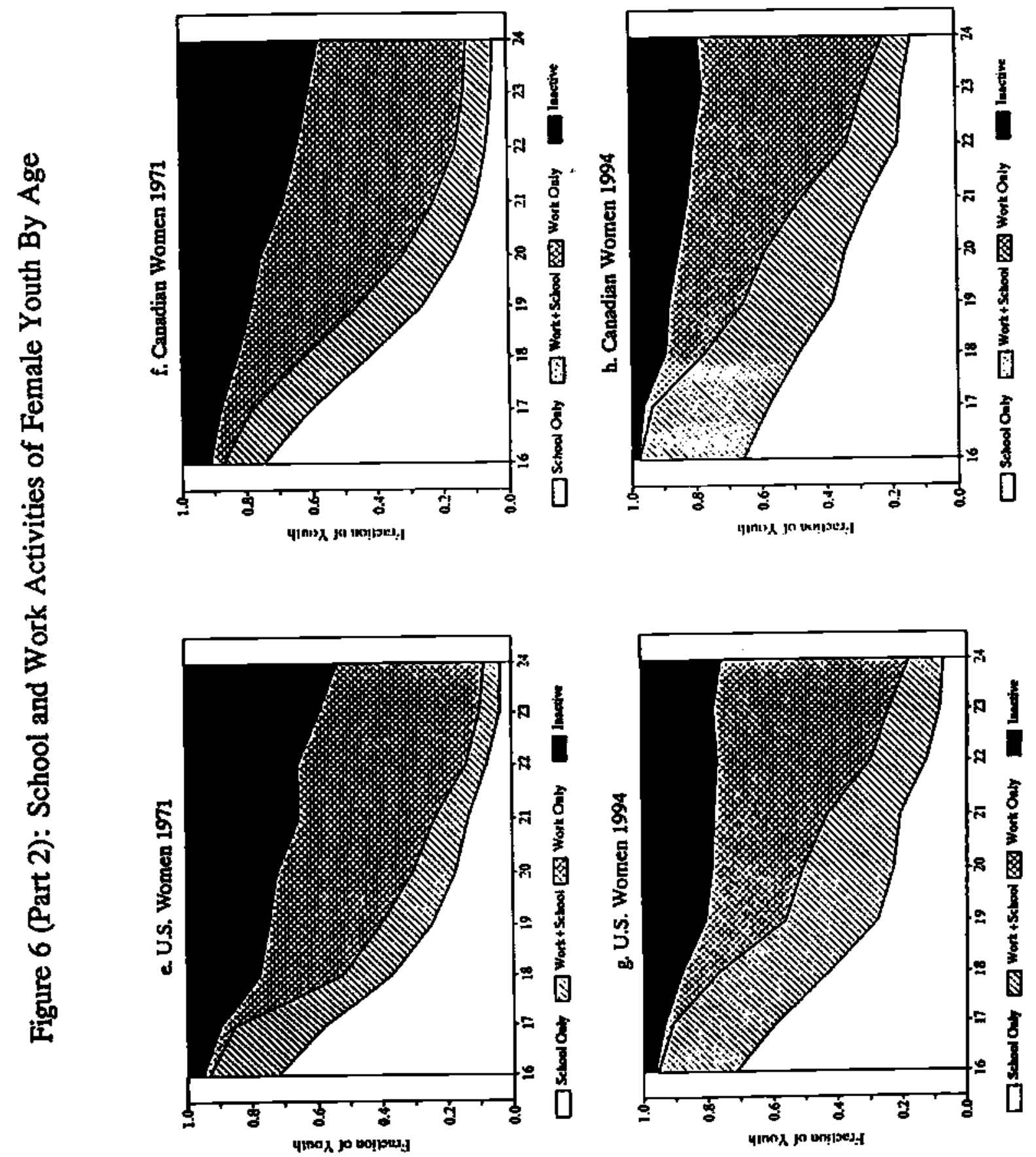




\section{Appendix Figure 1: Regional Variation in Youth Wages}
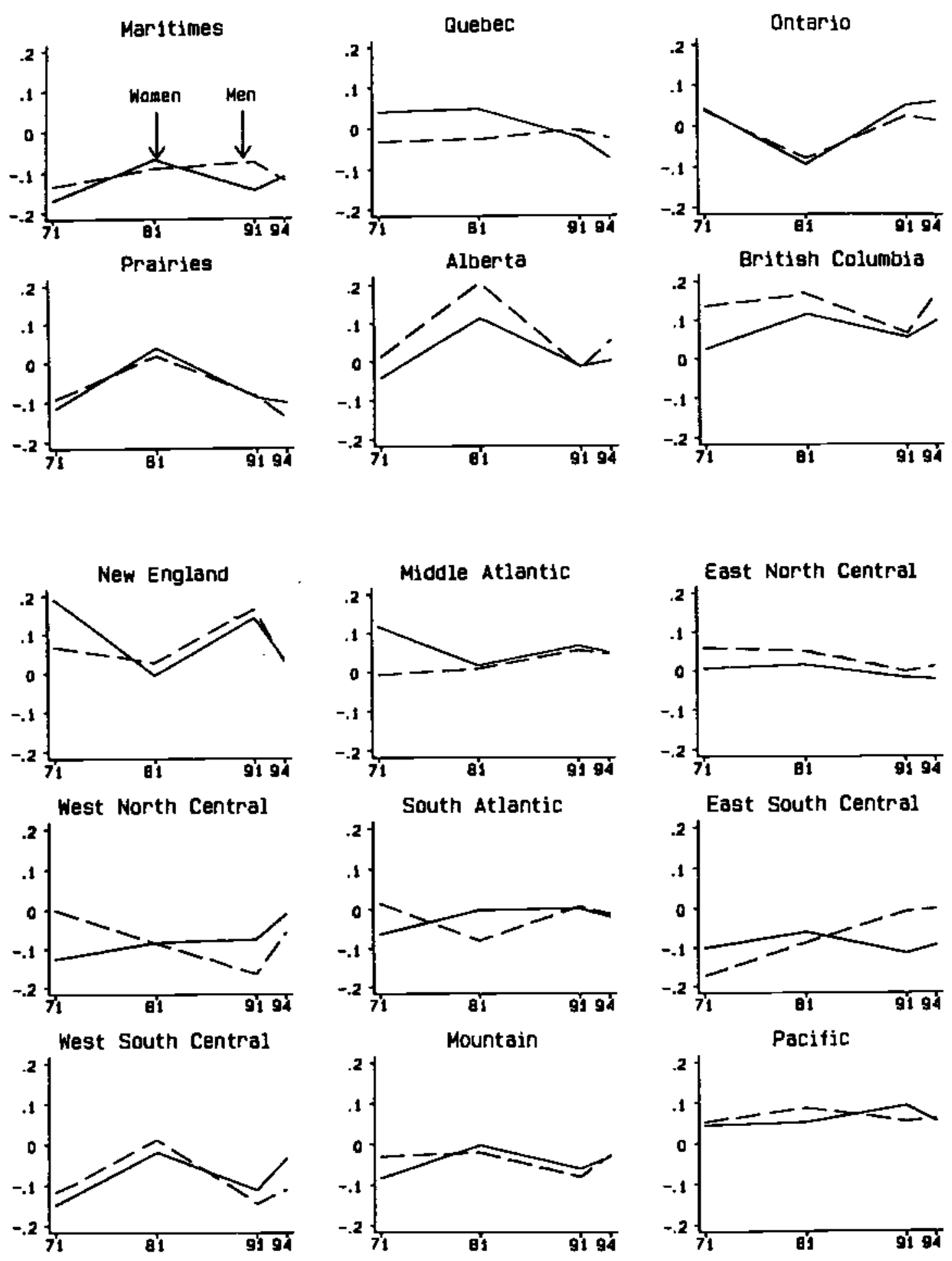


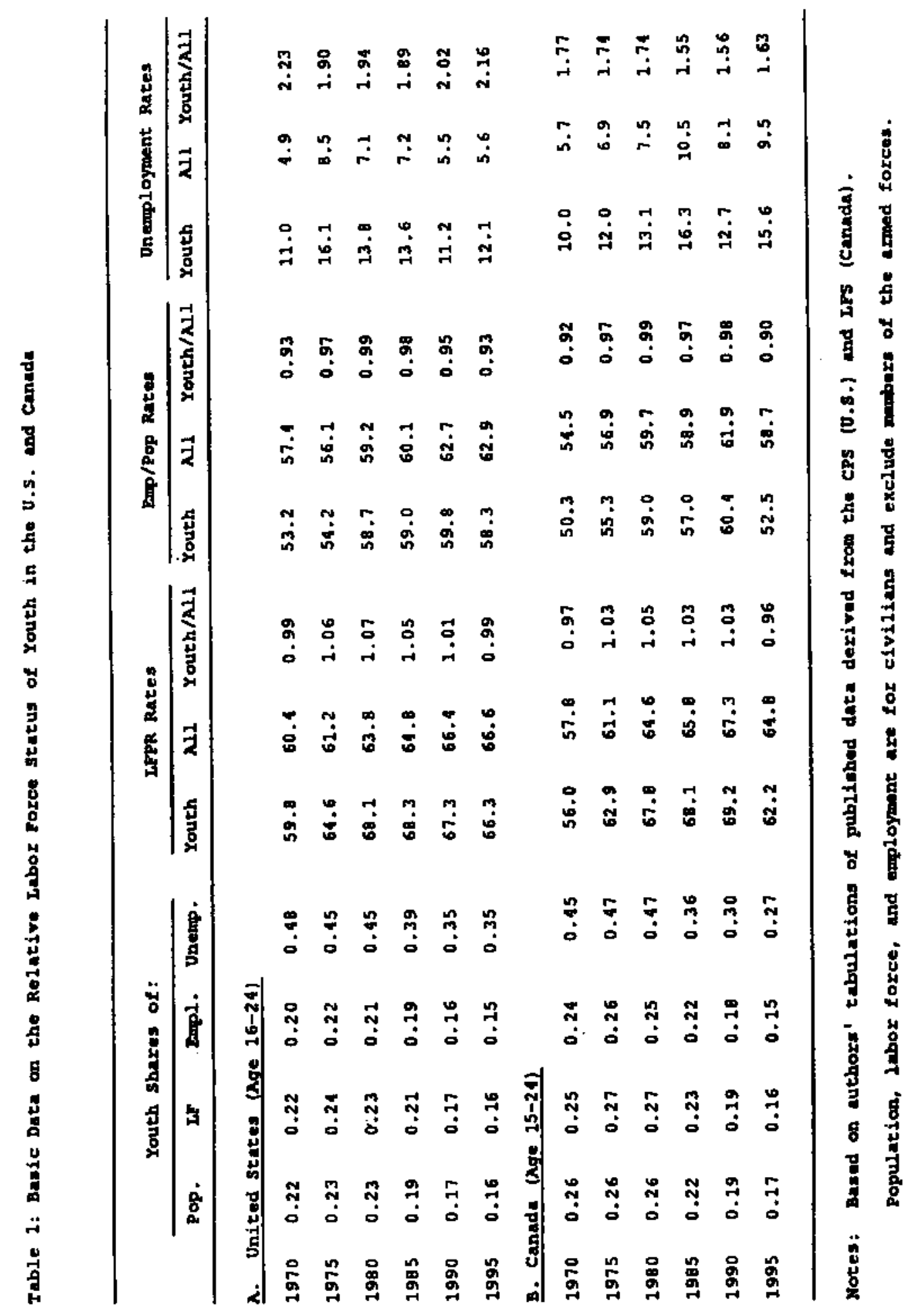


Table 2: Inequality in Adjusted Family Income and Position of Youths in the Family Income Distribution*

1. Share of Adjusted Eamily Income (in percentage) by Quartile among Individuals of all Ages ${ }^{\mathrm{b}}$

\begin{tabular}{|c|c|c|c|c|c|c|c|c|}
\hline & \multicolumn{4}{|c|}{ United States } & \multicolumn{4}{|c|}{ Canada } \\
\hline & 1970 & 1980 & 1990 & 1993 & 1970 & 1980 & 1990 & 1993 \\
\hline bottom $1 / 4$ & 7.3 & 7.5 & 6.5 & 6.2 & 6.9 & 7.7 & 7.9 & 9.2 \\
\hline 2nd quartile & 17.2 & 17.3 & 16.1 & 15.7 & 17.1 & 17.3 & 17.6 & 18.4 \\
\hline 3rd quartile & 26.2 & 27.1 & 26.3 & 26.3 & 26.4 & 26.6 & 27.0 & 27.8 \\
\hline cop quartile & 48.8 & 48.2 & 51.1 & 51.9 & 49.6 & 48.4 & 47.5 & 44.6 \\
\hline
\end{tabular}

2. Eraction of Youth (in percentage) by Quartile of Adjusted Family Income Distribution

\begin{tabular}{|c|c|c|c|c|c|c|c|c|}
\hline & & iited & States & & & Cani & & \\
\hline & 1970 & 1980 & 1990 & 1993 & 1970 & 1980 & 1990 & 1993 \\
\hline bottom $1 / 4$ & 26.5 & 28.5 & 32.6 & 33.9 & 24.1 & 25.5 & 28.5 & 26.4 \\
\hline 2nd quartile & 26.5 & 25.9 & 24.9 & 25.6 & 25.7 & 25.7 & 24.0 & 24.1 \\
\hline rd quartile & 25.9 & 25.7 & 23.4 & 22.1 & 26.7 & 26.1 & 24.8 & 25.8 \\
\hline प̧u & 21.1 & 19.8 & 19.1 & 18.4 & 23.5 & 22.7 & 22.7 & 23.7 \\
\hline
\end{tabular}

Notes:

a. U.S. data based on the March CPS. Canadian data based on the Census (1970, 1980, and 1990) and the SCF (1993). Families are "economic" families in the "CPS and the SCF but "Census" families in the Canadian Census. See text for details.

b. Adjusted family income is family income divided by the poverty level (low income cutoff in Canada) for a family of this size. 
Table 3: Ltving Arrangements of Youth tn Canada and the Untted States

\section{A. Nax}

\begin{tabular}{|c|c|c|c|c|c|c|c|c|}
\hline \multirow[b]{2}{*}{. } & \multicolumn{4}{|c|}{ United states } & \multicolumn{4}{|c|}{ Canada } \\
\hline & 1971 & 1981 & 1991 & 1994 & 1971 & 1981 & 1991 & 1994 \\
\hline Living with parents & 71.9 & 70.7 & 74.0 & 74.2 & 70.3 & 68.6 & 73.8 & 77.3 \\
\hline $\begin{array}{l}\text { Husband/wife family } \\
\text { Single headed family }\end{array}$ & $\begin{array}{l}58.3 \\
13.6\end{array}$ & $\begin{array}{l}52.6 \\
18.1\end{array}$ & $\begin{array}{l}52.3 \\
21.7\end{array}$ & $\begin{array}{l}52.3 \\
22.0\end{array}$ & --- & $\begin{array}{l}57.5 \\
11.1\end{array}$ & $\begin{array}{l}60.8 \\
12.9\end{array}$ & $\begin{array}{l}65.1 \\
12.1\end{array}$ \\
\hline $\begin{array}{l}\text { Head or apouse of } \\
\text { own fantly } \\
\text { Married } \\
\text { Single parent }\end{array}$ & $\begin{array}{r}21.2 \\
0.5\end{array}$ & $\begin{array}{r}14.7 \\
1.2\end{array}$ & $\begin{array}{l}9.6 \\
1.6\end{array}$ & $\begin{array}{l}\text { 8.8 } \\
1.9\end{array}$ & $\begin{array}{r}15.5 \\
15.3 \\
0.2\end{array}$ & $\begin{array}{r}15.3 \\
15.2 \\
0.1\end{array}$ & $\begin{array}{l}9.9 \\
9.8 \\
0.1\end{array}$ & $\begin{array}{l}7.8 \\
8.0 \\
0.1\end{array}$ \\
\hline Ltving alone & 6.4 & 13.4 & 14.8 & 15.1 & 14.5 & 16.1 & 16.3 & 14.9 \\
\hline
\end{tabular}

\begin{tabular}{|c|c|c|c|c|c|c|c|c|}
\hline & \multicolumn{4}{|c|}{ United states } & \multicolumn{4}{|c|}{ Canada } \\
\hline & 1971 & 1981 & 1991 & 1994 & 1971 & 1981 & 1991 & 1994 \\
\hline Living with parents & 57.8 & 58.7 & 62.5 & 62.3 & 55.0 & 55.3 & 62.4 & 66.3 \\
\hline $\begin{array}{l}\text { Husband/wife family } \\
\text { single headed family }\end{array}$ & $\begin{array}{l}47.2 \\
10.6\end{array}$ & $\begin{array}{l}43.9 \\
14.9\end{array}$ & $\begin{array}{l}44.2 \\
18.3\end{array}$ & $\begin{array}{l}43.0 \\
19.3\end{array}$ & $\begin{array}{l}--- \\
---\end{array}$ & $\begin{array}{r}46.7 \\
8.6\end{array}$ & $\begin{array}{l}51.7 \\
10.8\end{array}$ & $\begin{array}{r}56.7 \\
9.4\end{array}$ \\
\hline $\begin{array}{l}\text { Head or spouse of } \\
\text { own family }\end{array}$ & 35.8 & 29.6 & 24.3 & 23.6 & 31.5 & 30.4 & 22.9 & 19.7 \\
\hline $\begin{array}{l}\text { Married } \\
\text { single parent }\end{array}$ & $\begin{array}{r}33.2 \\
2.7\end{array}$ & $\begin{array}{r}25.1 \\
4.5\end{array}$ & $\begin{array}{r}17.9 \\
6.5\end{array}$ & $\begin{array}{r}16.0 \\
7.7\end{array}$ & $\begin{array}{r}30.4 \\
1.1\end{array}$ & $\begin{array}{r}28.4 \\
1.9\end{array}$ & $\begin{array}{r}20.0 \\
2.9\end{array}$ & $\begin{array}{r}16.8 \\
3.1\end{array}$ \\
\hline Ltving alone & 6.4 & 11.6 & 13.1 & 14.1 & 13.5 & 14.3 & 14.7 & 14.1 \\
\hline
\end{tabular}

Notes: U.S. data based on the March cPs. Canadian data based on the census (1971, 1981, and 1991) and the SCF (1994). See text for detaila. 
Table 4: Effect of Living Arrangement status on the Eraction of Youth by Quartile of Adjusted Eamlly Income Distribution

1. Eraction of Youth by Quartile: United States

\begin{tabular}{|c|c|c|c|c|c|c|c|}
\hline & \multicolumn{3}{|c|}{1970} & \multicolumn{3}{|c|}{1993} & \multirow{2}{*}{$\begin{array}{l}1993 \text { with } \\
1970 \text { family } \\
\text { arrangements }\end{array}$} \\
\hline & $\begin{array}{l}\text { Llve } \\
\text { Alone }\end{array}$ & $\begin{array}{l}\text { with } \\
\text { parentg }\end{array}$ & Al1 & $\begin{array}{l}\text { Live } \\
\text { alone }\end{array}$ & $\begin{array}{l}\text { with } \\
\text { parents }\end{array}$ & Al1 & \\
\hline bottom $1 / 4$ & 31.2 & 24.0 & 26.5 & 50.1 & 26.4 & 33.9 & 34.8 \\
\hline 2nd quartile & 30.5 & 24.3 & 26.5 & 30.5 & 23.4 & 25.6 & 25.9 \\
\hline 3rd quartile & 24.6 & 26.7 & 25.9 & 14.6 & 25.5 & 22.1 & 21.7 \\
\hline top quartile & 13.7 & 25.1 & 21.1 & 4.8 & 24.7 & 18.4 & 17.7 \\
\hline $\begin{array}{l}\text { Percentage } \\
\text { of youth: }\end{array}$ & 35.4 & 64.6 & 100.0 & 31.7 & 68.3 & 100.0 & 100.0 \\
\hline
\end{tabular}

2. Eraction of Youth by Quartile: Canada

\begin{tabular}{lllll}
\multicolumn{2}{c}{1970} & & 1993 & $\begin{array}{c}1993 \text { with } \\
1970 \text { family } \\
\text { Live with All } \\
\text { Alone parents }\end{array}$
\end{tabular}

$\begin{array}{llllllll}\text { bottom 1/4 } & 31.5 & 19.6 & 24.1 & 49.9 & 16.5 & 26.4 & 29.8 \\ \text { 2nd quartile } & 25.9 & 25.6 & 25.7 & 24.6 & 23.9 & 24.1 & 24.1 \\ \text { 3rd quartile } & 24.4 & 28.1 & 26.7 & 15.1 & 30.4 & 25.8 & 24.8 \\ \text { top quartile } & 18.3 & 26.6 & 23.5 & 10.4 & 29.3 & 23.7 & 21.8 \\ \begin{array}{l}\text { Percentage } \\ \text { of youth: }\end{array} & 37.7 & 62.3 & 100.0 & 29.7 & 70.3 & 100.0 & 100.0\end{array}$

Note: v.s. data based on the March CPS. Canadian data based on the census (1970) and the SCE (1993). The category "Live Alone" includes all youth who do not live with, their parents. The last colum of the table (1993 distribution with 1970 family arrangements) indicates the distribution of youth that would have prevailed in 1993 if the fraction of youth living with their parents had remained as in 1970 . see text for details. 
Table 5: Inequality in Annual Earnings and Postion of Youth in the Earnings Distribution

\section{A. MEN}

1. Earnings Shares (in percentage) by Quartile among Men (age 16 and more) with Positive Earnings

United states

$\begin{array}{llll}1970 \quad 1980 & 1990 & 1993\end{array}$

\section{Canada}

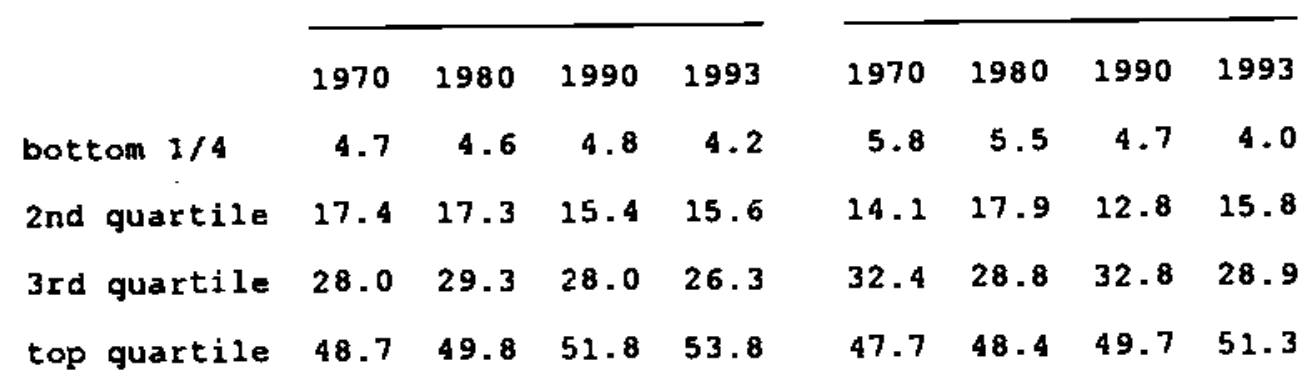

2. Eraction (in percentage) of Young Men with Positive Earnings by Quartile of the Male Earnings Distribution

United states

$\overline{1970 \quad 1980 \quad 1990 \quad 1993}$

bottom $1 / 4$

65.$$
\begin{array}{lll}
60.7 & 66.6 & 67.2
\end{array}
$$$$
\begin{array}{lll}
27.8 & 24.3 & 25.1
\end{array}
$$$$
\begin{array}{llll}
9.8 & 9.6 & 7.9 & 6.3
\end{array}
$$$$
2.02 .0
$$$$
1.2
$$$$
1.4
$$

3 rd guartile

top quartile

2.0

$$
1.2
$$

Canada

\begin{tabular}{rrrr}
\hline 1970 & 1980 & 1990 & 1993 \\
59.9 & 59.9 & 69.4 & 68.6 \\
29.3 & 26.8 & 23.5 & 23.5 \\
0.0 & 11.6 & 6.4 & 5.9 \\
2.9 & 1.7 & 0.7 & 2.1
\end{tabular}

Notes: U.S. data based on the March CPS. Canadian data based on the Census (1970, 1980, and 1990) and on the SCF (1993). Earnings are defined as all wages and salaries received during the year. 
Table 5: continuation

B. WOMEN

1. Earnings Shares (in percentage) by Quartile among Women (age 16 and more) with Positive Earnings

United states

Canada

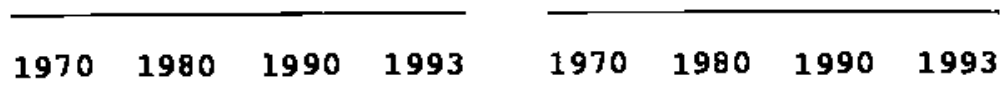

$\begin{array}{lrrrrrrrr}\text { bottom 1/4 } & 2.7 & 3.5 & 3.8 & 3.5 & 4.0 & 3.7 & 4.1 & 3.8 \\ \text { 2nd quartile } & 12.8 & 14.2 & 14.2 & 14.7 & 15.0 & 15.1 & 15.0 & 14.2 \\ \text { 3rd quartile } & 29.1 & 28.7 & 27.6 & 26.7 & 29.0 & 29.0 & 28.6 & 28.7 \\ \text { top quartile } & 55.5 & 53.5 & 54.4 & 55.1 & 52.0 & 52.2 & 52.3 & 53.3\end{array}$

2. Eraction (in percentage) of Young Women with Positive Earnings by Quartile of the Female Earnings Distribution

\begin{tabular}{|c|c|c|c|c|c|c|c|c|}
\hline & \multicolumn{4}{|c|}{ United states } & \multicolumn{4}{|c|}{ Canada } \\
\hline & 1970 & 1980 & 1990 & 1993 & 1970 & 1980 & 1990 & 1993 \\
\hline bottom $1 / 4$ & 40.3 & 43.5 & 53.1 & 54.8 & 36.0 & 39.5 & 54.5 & 56.3 \\
\hline 2nd quartile & 28.3 & 27.4 & 27.4 & 28.3 & 25.8 & 28.6 & 27.5 & 26.7 \\
\hline 3rd quartile & 20.1 & 21.3 & 14.9 & 13.7 & 28.5 & 26.2 & 15.7 & 12,4 \\
\hline top quartile & 11.4 & 7.8 & 4.5 & 3.2 & 9.7 & 5.7 & 2.3 & 4.6 \\
\hline
\end{tabular}

Notes: U.S. data based on the March CPS. Canadian data based on the Census (1970, 1980, and 1990) and on the SCF (1993). Earnings are defined as all wages and salaries received during the year. 
Table 6: Activity Rates of Youth in Canada and the United states

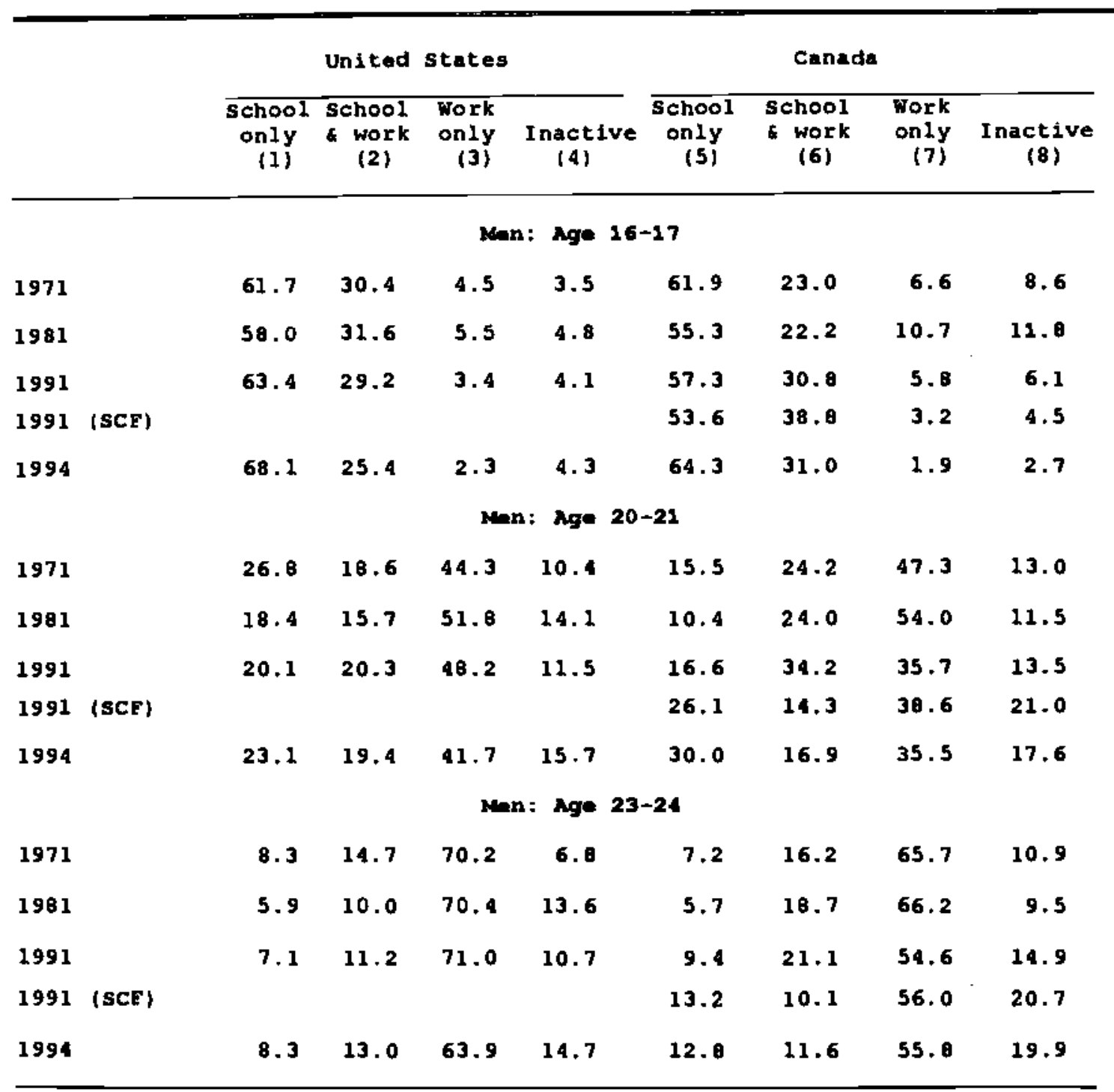

Note: U.S. data for 1971, 1981, and 1991 are from the october cPs; data for 1994 re from the March CPS. Canadian data for 1971, 1981, and 1991 are from the cenaus; data for 1994 are from the SCF. Data from the 1991 sCe are also reported. In the SCF and the CPS, enrollment and work activities refer to the survey week (April in the SCF). In the Canadian Census, enrollment refers to school attendance at any time over the 9 -month period from september of the previous year to the "Census week" (in June of the corresponding year), while work activity refers to the census week. 
United states

\begin{tabular}{cll}
\hline school school Work & \\
only 4 work only Inactive
\end{tabular}

(1)

(2)

(3)

(4)

(6)

(7)

(8)

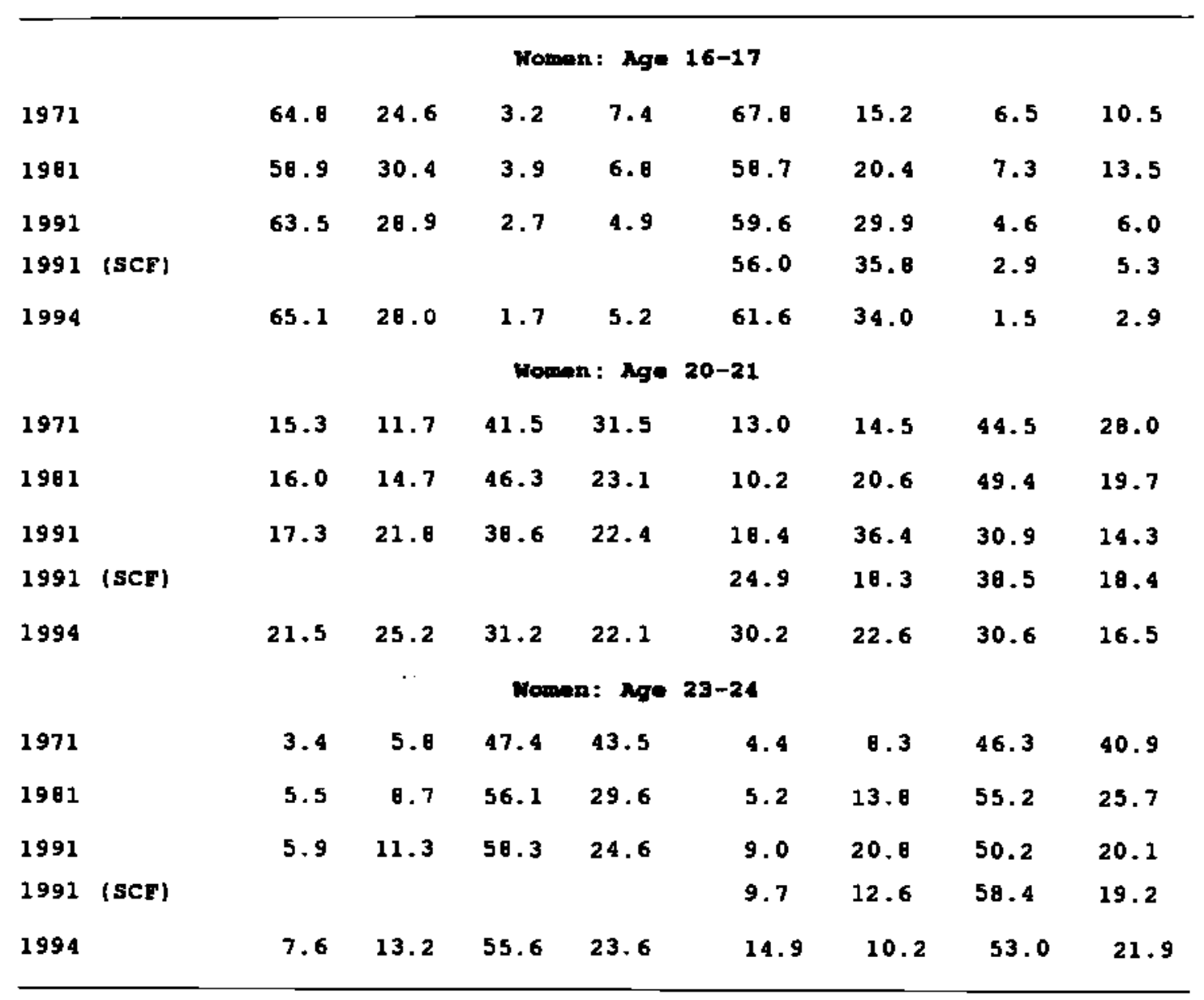

Note: U.s. data for 1971, 1981 , and 1991 are from the october crs; data for 1994 are from the March CPS. Canadian data for 1971, 1981, and 1991 áre from the Census data for 1994 are from the SCF. Data from the 1991 sCF are also reported. In the SCF and the CPS, enrollment and work activities refer to the survey week (April in the SCF). In the Canadian Census, enrollment refers to school attendance at any time over the 9 -month period from september of the previous year to the "Census week" (in June of the corresponding year), while work activity refers to the census week. 
Table 7: Proportion of Youth Receiving Felfare Payments in the United states and Canada

\begin{tabular}{|c|c|c|c|c|c|c|c|c|}
\hline & \multicolumn{4}{|c|}{ All Youth } & \multicolumn{4}{|c|}{$\begin{array}{l}\text { Youth not living } \\
\text { with their parents }\end{array}$} \\
\hline & \multicolumn{2}{|c|}{$\begin{array}{l}\text { United } \\
\text { states }\end{array}$} & \multicolumn{2}{|c|}{ Canada } & \multicolumn{2}{|c|}{$\begin{array}{l}\text { United } \\
\text { states }\end{array}$} & \multicolumn{2}{|c|}{ Canada } \\
\hline & Men & Homen & Men & Homen & Men & Homen & Men & Homen \\
\hline 1970 & 1.0 & 2.6 & $--\infty$ & -- & 2.1 & 4.4 & --- & $\rightarrow \infty-$ \\
\hline 1980 & 1.2 & 5.7 & --- & $-\sim-$ & 1.6 & 6.8 & --- & -- \\
\hline 1990 & 0.9 & 6.8 & 3.6 & 5.3 & 1.3 & 12.9 & B. 4 & 11.2 \\
\hline 1993 & 1.0 & 7.9 & 6.3 & 7.4 & 0.9 & 14.1 & 15.4 & 17.8 \\
\hline
\end{tabular}

Note: U.S. data are from the Harch CPS. Canadian data are from the SCF. 
Table 8: Fraction (1n percentage) of Youth who ilve at Home, Work, and Ara Enrolled in School by Region, 1971 and 1994

\begin{tabular}{|c|c|c|c|c|c|}
\hline \multicolumn{3}{|c|}{1971} & \multicolumn{3}{|c|}{1994} \\
\hline $\begin{array}{l}\text { Iive at } \\
\text { home }\end{array}$ & Work & Entolled & $\begin{array}{l}\text { Llve th } \\
\text { home }\end{array}$ & Work & Encolled \\
\hline
\end{tabular}

(1)

(2)

(3)

(4)

(5)

(6)

1. Onited steter

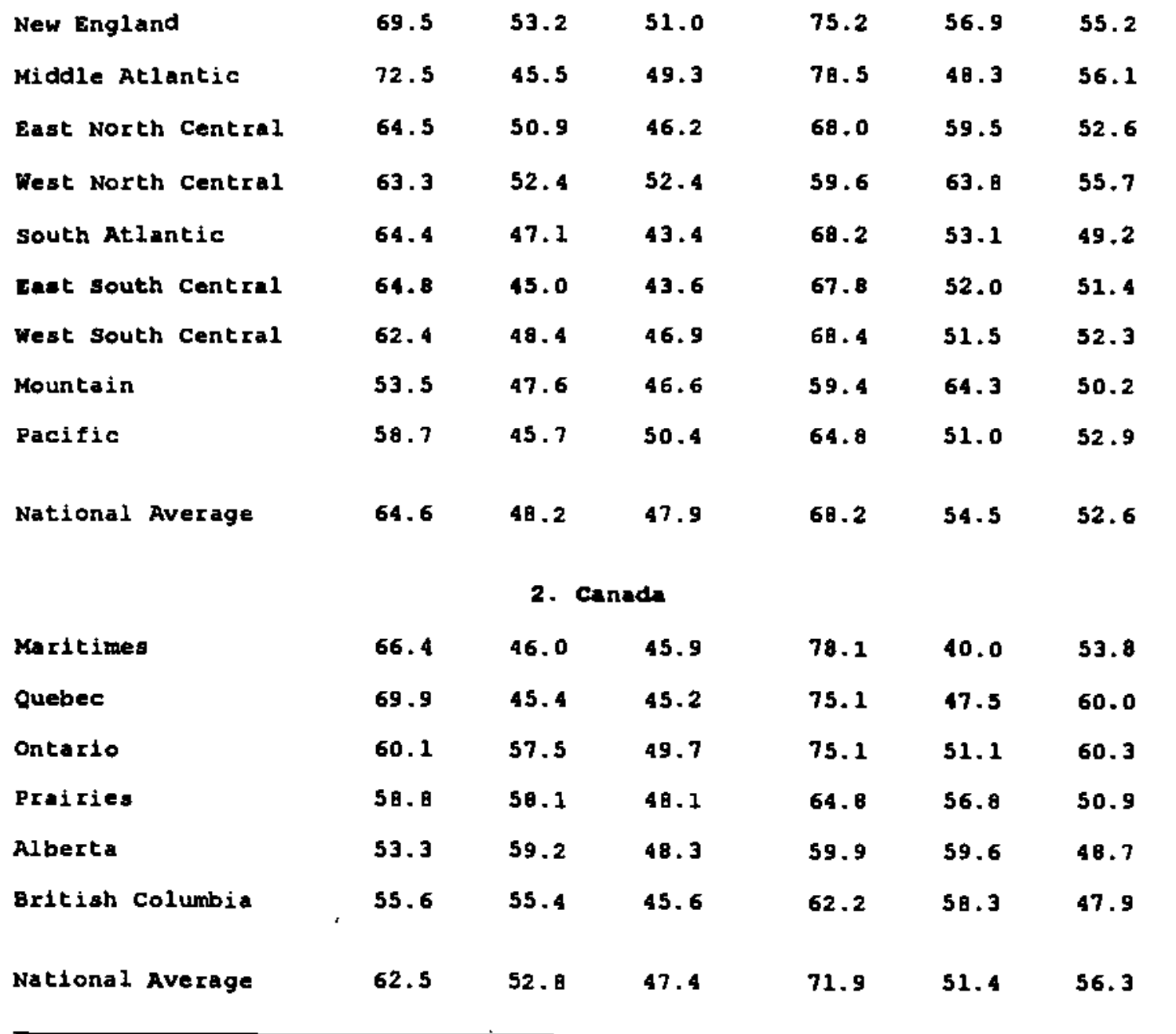

Note: U.S. data based on the cPs. Canadian data based on the Census (1971) and the SCF (1994). In the SCF and the CPS, enrollment and work activities refer to the survey week (April in the SCF). In the canadian Censua, enrollment refers to school attendance at any time over the 9-month period from September of the previous year to the "Census Week" (in June of the corresponding year), while work activity refer to the Census week. 
Table 9: OLs estimates of the Impact of wages and Cyclical Factors on Youth outcome:

Dep- variable: Proportion of Youth
$\begin{gathered}\text { iiving with Working Attending Receiving } \\ \text { parents } \\ \text { (1) }\end{gathered}-\frac{\begin{array}{c}\text { School } \\ \text { (2) }\end{array}}{\text { (3) }} \frac{\text { (4) }}{}$

\begin{tabular}{|c|c|c|c|c|}
\hline \multicolumn{5}{|l|}{ 1. United states } \\
\hline $\begin{array}{l}\text { Average log wage } \\
\text { of 16-24 years old }\end{array}$ & $\begin{array}{l}-0.127 \\
(0.057)\end{array}$ & $\begin{array}{c}0.002 \\
(0.084)\end{array}$ & $\begin{array}{l}-0.087 \\
(0.042)\end{array}$ & $\begin{array}{l}-0.010 \\
\{0.011\}\end{array}$ \\
\hline $\begin{array}{l}\text { Employment-pop. ratio } \\
\text { of men aged } 25-45\end{array}$ & $\begin{array}{l}-0.378 \\
(0.190)\end{array}$ & $\begin{array}{c}1.326 \\
(0.252)\end{array}$ & $\begin{array}{l}-0.722 \\
\{0.171\}\end{array}$ & $\begin{array}{l}-0.064 \\
(0.032)\end{array}$ \\
\hline \multicolumn{5}{|l|}{ 2. Canada } \\
\hline $\begin{array}{l}\text { Average log wage } \\
\text { of 16-24 years old }\end{array}$ & $\begin{array}{l}-0.190 \\
(0.071)\end{array}$ & $\begin{array}{c}0.008 \\
\{0.055\}\end{array}$ & $\begin{array}{l}-0.102 \\
(0.044)\end{array}$ & $\begin{array}{c}-0.289 \\
(0.084)\end{array}$ \\
\hline $\begin{array}{l}\text { Employment-pop. ratio } \\
\text { of man aged 25-45 }\end{array}$ & $\begin{array}{l}-0.472 \\
(0.238)\end{array}$ & $\begin{array}{l}1.173 \\
(0.290)\end{array}$ & $\begin{array}{l}-0.105 \\
(0.229)\end{array}$ & $\begin{array}{c}0.614 \\
(0.227)\end{array}$ \\
\hline \multicolumn{5}{|c|}{ 3. United states and canada } \\
\hline $\begin{array}{l}\text { Average log wage } \\
\text { of 16-24 yenrs old }\end{array}$ & $\begin{array}{l}-0.163 \\
(0.049)\end{array}$ & $\begin{array}{c}0.004 \\
(0.048)\end{array}$ & $\begin{array}{l}-0.090 \\
(0.032)\end{array}$ & $\begin{array}{l}-0.030 \\
(0.015\}\end{array}$ \\
\hline $\begin{array}{l}\text { Bmployment-pop. ratio } \\
\text { of men aged } 25-45\end{array}$ & $\begin{array}{l}-0.434 \\
(0.157)\end{array}$ & $\begin{array}{l}1.232 \\
(0.204)\end{array}$ & $\begin{array}{l}-0.368 \\
(0.175)\end{array}$ & $\begin{array}{c}-0.032 \\
(0.053)\end{array}$ \\
\hline
\end{tabular}

Notea:

sample consists of age $x$ region $x$ year cells: all models also include unrestricted age, region, and year effects, as well as interactions between age and the wage and employment-population ratio (of men aged 25-44) variables. The reported wage and employment-population ratio effects are for youth of age 20 .

There are 6 regions in Canada and 9 regions in the U.s. (see Table 8 ). Years are 1970, 1980, 1990 and 1993. The models are thus eatimated using 324 age $x$ region $x$ year celis for the U.s. and 216 cells for canada, except for the Canadian welfare models in which only the years 1990 and 1993 are available.

pooled U.s. and Canada models include country $x$ year effects.

standard errors (in parentheses) are adjusted for arbitrary forms of heteroskedasticity and for residual correlation among age groups within ach year $x$ region cell. 
Dep. variable: Proportion of Youth

$\frac{\begin{array}{c}\text { Living with working } \\ \text { parents }\end{array}}{\text { (1) }} \frac{\begin{array}{c}\text { Attending } \\ \text { school }\end{array}}{(2)} \frac{\begin{array}{c}\text { Receiving } \\ \text { Welfare }\end{array}}{\text { (3) }} \frac{\text { (4) }}{2}$

\section{B. wosin:}

1. United states

$\begin{array}{ccccc}\text { Average Log wage } & -0.110 & -0.041 & -0.089 & -0.039 \\ \text { of 16-24 years old } & (0.060) & (0.095) & (0.036) & (0.031) \\ & & & & \\ \text { Employment-pop. rat10 } & -0.159 & 0.687 & 0.193 & 0.208 \\ \text { of women aged 25-45 } & (0.134) & (0.189) & (0.089) & (0.072)\end{array}$

2. Canada

$\begin{array}{ccccc}\text { Average Log wage } & -0.219 & 0.095 & -0.131 & 0.045 \\ \text { of 16-24 years old } & (0.054) & (0.087) & (0.007) & (0.125) \\ & & & & 0.197 \\ \text { Employment-pop. ratio } & -1.479 & 0.861 & 0.472 \\ \text { of women aged 25-45 } & (0.262) & (0.318) & (0.344) & (0.285)\end{array}$

3. United states and Canada

$\begin{array}{lcccc}\text { Average Log wage } & -0.102 & 0.045 & -0.114 & -0.033 \\ \text { of 16-24 years old } & (0.048) & (0.056) & (0.059) & (0.031) \\ & & & & \\ \text { Employment-pop. ratio } & -0.689 & 0.732 & 0.198 & 0.234 \\ \text { of women aged 25-45 } & (0.193) & (0.166) & (0.151) & (0.071)\end{array}$

Notes:

sample consiats of age $x$ region $x$ year cella: all model: also include unrestricted age, region, and year effects, as well as interactions between age and the wage and employment-population ratio (of men aged 25-44) variables. The reported wage and employment-population ratio effects are for youth of age 20 .

There are 6 regions in Canada and 9 regions in the U.s. (gee rable 8 ). Years are 1970, 1980, 1990 and 1993. The models are thus estimated using 324 age $x$ region $x$ year cells for the U.S. and 216 cells for Canada, except for the Canadian welfare models in which only the years 1990 and 1993 are available.

Pooled U.S. and Canada models include country $x$ year effects.

standard errors (in parentheses) are adjusted for arbitrary forms of heteroskedasticity and for residual correlation among age groups within each year $x$ region cell. 
Table 10: Effect of Labor Market Conditions on Canada-U,s, Differences in the percentage of Youth Living with Parents, Working, and Enrolled in School*

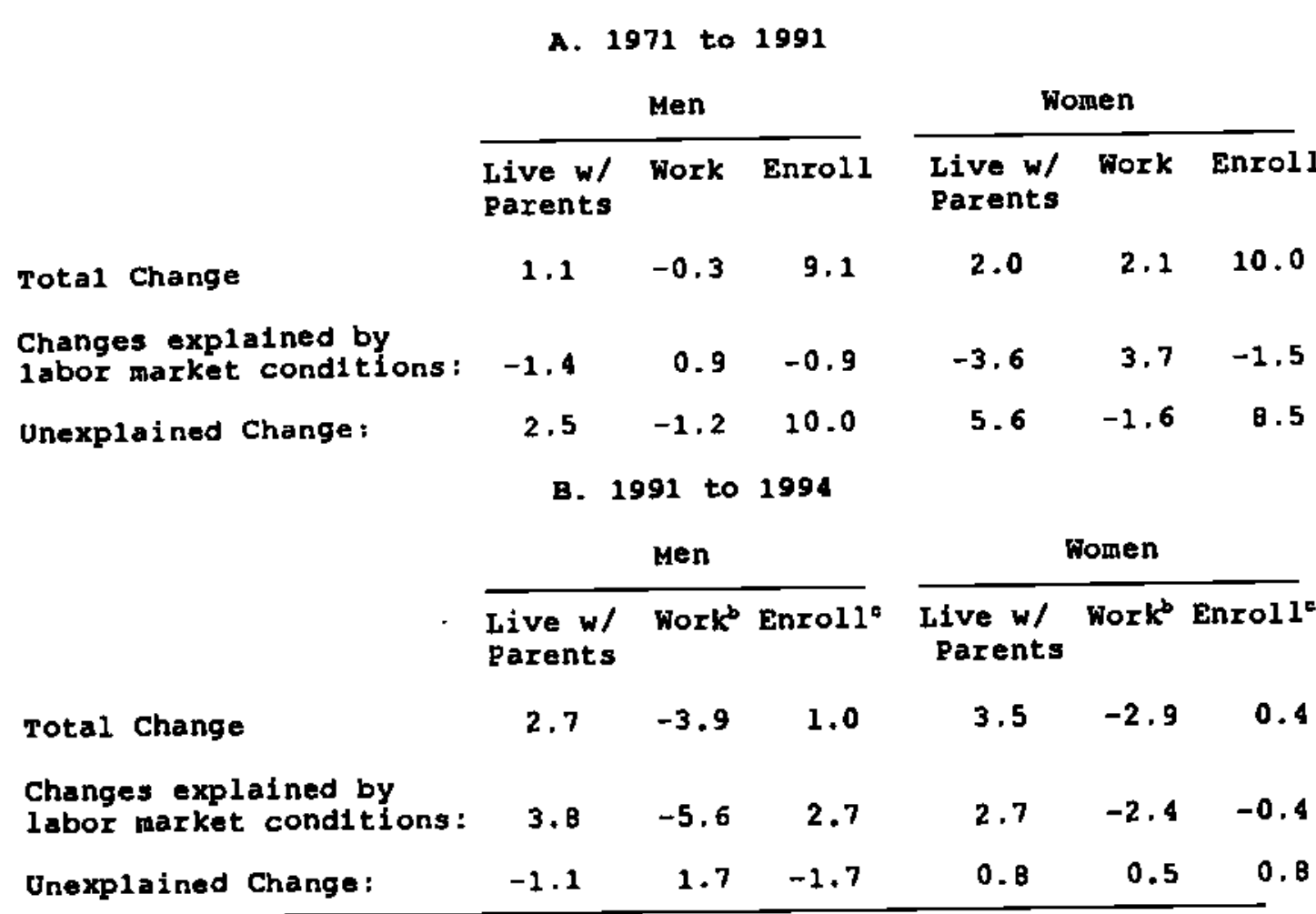

Notes:

a. The row label led "Total Change" is calculated from the estimated coefficients (translated in percentage points) on the full set of interactions between country and year effects when the labor market variables (adult employment-population rate and wage index) are not included in the pooled U.S.-Canada model (see Panel 3, or Table 9). The row entitled "Changes Explained by Labor Market Conditions" indicates how the estimated coefficient change when the labor market variables are included in the regression models.

$b$. The change in the fraction of youth working has been adjusted to account for changes in the definition of employment in the canadian data (work in the reference week in June in the 1991 Census versus work in the reference week in April in the 1994 SCE). The adjustment factor of 5.4 percentage points was obtained by comparing the fraction of youth working in the 1991 Census and in the 1991 SCF.

$c$. The change in the fraction of youth enrolled in school has been adjusted to account for changes in the definition of school enrollment in the canadian data (enrolled at any time in the 9 months before June in the 1991 Census versus enrolled in the reference week in April in the $1994 \mathrm{SCE}$. The adjustment factor of 7.1 percentage points was obtained by comparing the fraction of youth working in the 1991 Census and in the 1991 SCF. 
Appendix Tablo A: Estimated Regression Coefficients of Living Arrangement Status on Log wages of Youth

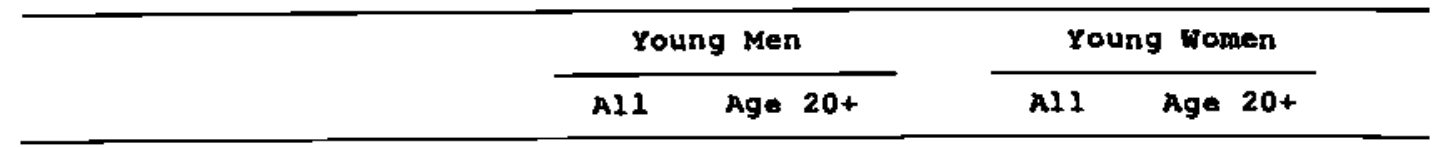

\section{$\boldsymbol{\lambda}$. United states}

1. 1970 Weekly Earnings Controlling for hours in survey week
a. live alone
0.06
0.07
0.15
0.16
(0.04)
(0.04)
$(0.03)$
$(0.03)$
b. head own tamily

$\begin{array}{cc}0.34 & 0.34 \\ (0.02) & (0.02)\end{array}$
0.10
0.11
$(0.02)$
(0.02)
(0.02)
$(0.02)$

2. 1980 Weekly Earnings Controlling for hours in survey week
a. live alone
0.16
0.16
0.12
0.11
(0.02)
(0.02)
(0.02)
$(0.02)$
b. head own tamily

$\begin{array}{cc}0.27 & 0.27 \\ (0.02) & (0.02)\end{array}$
0.12
$(0.02)$
0.12
$(0.02)$

0.11

0.13

0.04

$(0.01)$

0.06

a. live alone

(0.01)

$(0.02)$

0.06

(0.01)

b. head own family

$\begin{array}{cc}0.22 & 0.23 \\ (0.01) & (0.02)\end{array}$

0.23
$(0.02\}$

0.06 .

0.07

$(0.02)$

0.05

(0.01)

0.07

(0.02)

0.12

0.11

$(0.02)$

0.02

$(0.02)$

$(0.02)$

b. head own family

$(0.02)$

(0.02)

0.13

0.14

(0.02)

0.01

$(0.02)$

0.02

a. live alone

(0.02)

0.17

0.00

$(0.02)$

b. head own farally

$\begin{array}{cc}0.16 & 0.17 \\ (0.02) & (0.02)\end{array}$

$(0.02)$

0.01

(0.02)

Noto: Table entries are estimated coefficients of living arrangement statug (living alone, living as head of one's own family) in a linear regression model for 109 average weekly earnings or log average hourly earnings over the previous calendar year. The omitted status is living with one's parents. Other covariates are age dumies, education, a nonwhite dumy, and region durmies. The models in rows 1 and 2 also include the log of reported hours in the CPS survey week (set to 0 for nonworkers) and an indicator for individuals who did not work in the survey week. Samples include individuals age 16-24 in the March CPS who reported positive earnings and weeks of work in the previous year. 


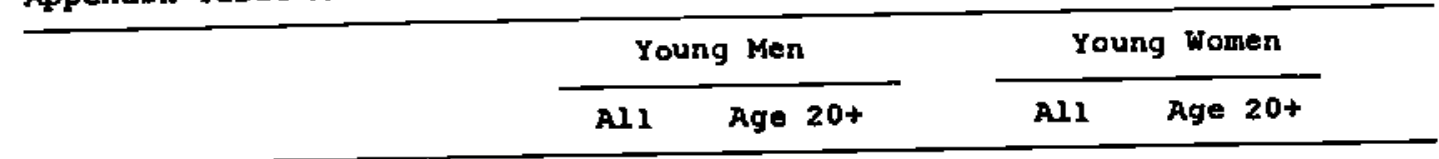

B. Canada

1. 1980 Weekly Earnings (Census) Controlling for houra in survey week
a. Live alone
0.10 0.09
0.08
0.07
b. Head own lamily.
(0.01)
(0.01)
(0.01)
(0.01)
$\begin{array}{cc}0.19 & 0.19 \\ (0.01) & (0.01)\end{array}$
0.10
0.10
$(0.01)$
$(0.01)$

2. 1990 Weekly Earnings (Census)

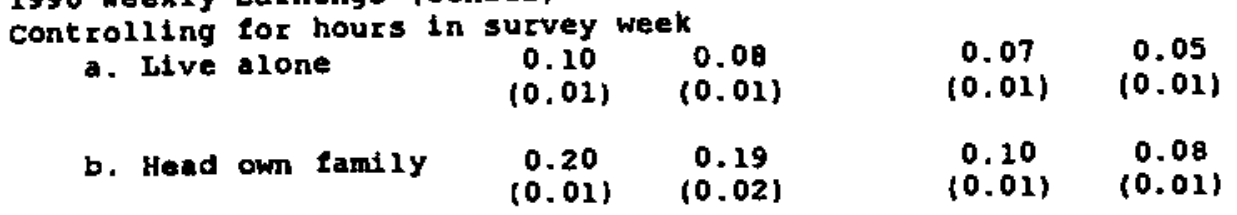

3. 1990 Weekly Earninge (SCF)

\begin{tabular}{|c|c|c|c|c|c|}
\hline a. Live & alone & $\begin{array}{c}0.22 \\
(0.03)\end{array}$ & $\begin{array}{c}0.22 \\
(0.03)\end{array}$ & $\begin{array}{c}0.10 \\
(0.03)\end{array}$ & $\begin{array}{c}0.10 \\
(0.03)\end{array}$ \\
\hline b. Heac & wh family & $\begin{array}{c}0.23 \\
(0.04)\end{array}$ & $\begin{array}{c}0.24 \\
(0.04)\end{array}$ & $\begin{array}{c}0.00 \\
(0.03)\end{array}$ & $\begin{array}{c}-0.01 \\
(0.03)\end{array}$ \\
\hline
\end{tabular}

4. 1993 Weekly Earnings (SCF)

controlling for hours in survey week
a. Iive alone
0.16
0.15
0.03
0.05
$(0.04)$
$(0.04)$
(0.04)
(0.04)
b. Head own tantly

$\begin{array}{cc}0.29 & 0.31 \\ (0.05) & (0.04)\end{array}$
0.01
$-0.02$
$(0.05)$
0.31
$(0.04)$
$(0.04)$
$(0.04)$

Note: Table entriea are estimated coefficients of living arrangement tatus (1iving alone, living as head of one's own famlyy in a linear regression model for log average weekly earnings or log average hourly earnings over the previous calendar year. The ondted status is living earnings over the previous calendar year. The omited ondes, education, and province dumies. The models in rows 1 and 2 also include the log of reported hours in the survey week (set to 0 for nonworkers) and an indicator for individuals who did not work in the survey week. Samples include individuals age 16-24 in the canadian Census (1980 and 1990) and the $\mathrm{SCE}$ (1990 and 1993) who reported positive earnings and weeks of work in the previous year. 
Appendix Table B: Activity Rates and Living Arrangements of Youth of Age 20 to 24 in Canada and the United states

\begin{tabular}{|c|c|c|c|c|c|c|}
\hline & \multicolumn{3}{|c|}{ United states } & \multicolumn{3}{|c|}{ Canada } \\
\hline & $\begin{array}{c}\text { All } \\
\text { youth } \\
\text { (1) }\end{array}$ & $\begin{array}{c}\text { Living w/ } \\
\text { parents } \\
\text { (2) }\end{array}$ & $\begin{array}{l}\text { Iiving } \\
\text { nlone } \\
\text { (3) }\end{array}$ & $\begin{array}{c}\text { All } \\
\text { youth } \\
\text { (4) }\end{array}$ & $\begin{array}{c}\text { Living } w / \\
\text { parents } \\
\text { (5) }\end{array}$ & $\begin{array}{l}\text { Itving } \\
\text { elone } \\
\text { (6) }\end{array}$ \\
\hline Inactive & 9.0 & 12.6 & Men: & $\begin{array}{r}1071 \\
11.9\end{array}$ & 15.0 & 8.6 \\
\hline school only & 16.4 & 26.1 & 7.7 & 11.2 & 17.0 & 5.2 \\
\hline Work a school & 16.1 & 17.1 & 15.2 & 20.9 & 24.1 & 17.5 \\
\hline work only & 58.5 & 44.1 & .71 .4 & 56.1 & 43.9 & 68.7 \\
\hline $\begin{array}{l}\text { Fraction of } \\
\text { all youth }\end{array}$ & 100.0 & 47.3 & 52.7 & 100.0 & 51.0 & 49.0 \\
\hline Inactive & 36.8 & 19.0 & $\begin{array}{l}\text { Nomen: } \\
44.7\end{array}$ & ; $\begin{array}{r}1071 \\
34.9\end{array}$ & 19.6 & 41.7 \\
\hline school only & 9.0 & 20.9 & 3.7 & B.1 & 17.4 & 4.0 \\
\hline Work a school & 8.3 & 13.8 & 5.9 & 10.9 & 17.3 & 8.2 \\
\hline work only & 45.9 & 46.3 & 45.7 & 46.0 & 45.7 & 46.2 \\
\hline $\begin{array}{l}\text { Eraction of } \\
\text { all youth }\end{array}$ & 100.0 & 30.8 & 69.2 & 100.0 & 30.6 & 69.4 \\
\hline Inactive & 15.2 & 16.8 & $\begin{array}{l}\text { Men: } \\
12.9\end{array}$ & $\begin{array}{r}1004 \\
19.1\end{array}$ & 17.3 & 22.2 \\
\hline School only & 15.4 & 20.9 & 7.3 & 21.0 & 26.4 & 11.9 \\
\hline Work school & 16.0 & 17.7 & 13.5 & 13.4 & 16.7 & 7.8 \\
\hline Work only & 53.4 & 44.5 & 66.2 & 46.5 & 39.6 & 58.2 \\
\hline $\begin{array}{l}\text { Eraction of } \\
\text { all youth }\end{array}$ & 100.0 & 59.0 & 41.0 & 100.0 & 63.2 & 36.8 \\
\hline Inactive & 23.0 & 16.3 & 28.2 & n: $\begin{array}{r}1094 \\
19.1\end{array}$ & 31.4 & 26.5 \\
\hline school only & 73.8 & 21.0 & B. 3 & 21.7 & 29.1 & 14.5 \\
\hline work achool & 38.6 & 26.0 & 12.8 & 16.4 & 23.9 & 9.2 \\
\hline Work only & 44.6 & 36.7 & 50.7 & 42.9 & 35.6 & 49.8 \\
\hline $\begin{array}{l}\text { Eraction of } \\
\text { all youth }\end{array}$ & 100.0 & 43.6 & 56.4 & 100.0 & 49.0 & 51.0 \\
\hline
\end{tabular}

Note: U.S. data based on the CPs. Canadian data based on the Census (1971) and the SCr (1994). In the SCF and the CPS, enrollment and work activities refer to the survey week (April in the SCF). In the Canadian Census, enrollment refers to school attendance at any time over the 9-month period from september of the previous year to the "Census week" (In June of the corresponding year), while work activity refer to the Census week. 